\title{
Morphometric analysis and prioritization of upper Benue River watershed, Northern Nigeria
}

\author{
Caleb Akoji Odiji ${ }^{1}$ - Olaide Monsor Aderoju ${ }^{2}$. Joseph Bisong Eta ${ }^{1} \cdot$ Idris Shehu ${ }^{1} \cdot$ Adama Mai-Bukar $^{1}$. \\ Hilda Onuoha ${ }^{1}$
}

Received: 5 October 2020 / Accepted: 7 January 2021 / Published online: 3 February 2021

(c) The Author(s) 2021

\begin{abstract}
The upper Benue River watershed is undergoing remarkable modifications due to man-made and natural phenomena. Hence, an evaluation is required to understand the hydrological process of the watershed for planning and management strategies. This study aimed to assess the morphometric characteristics and prioritize the upper Benue River watershed. The boundary of the watershed and sub-watersheds, as well as stream networks, was extracted from the digital elevation model (DEM) coupled with hydrological and topographic maps. Twenty-eight morphometric parameters under three categories, i.e. linear, areal, and relief aspects were computed and mapped. Findings from the study revealed that the watershed is a seventh stream order system characterized by a dendritic drainage pattern. The result also showed that 4821 streams were extracted with a cumulative length of $30,232.84 \mathrm{~km}$. The hypsometric integral of the watershed was estimated to be 0.22 , indicating that it is in the old stage. In the prioritization of the watershed, the morphometric variables were utilized to calculate and classify the compound factor. The result showed that sub-watersheds $12,16,18,24,26$, and 27 were ranked as very high priority for which conservation measures are required to mitigate the risk of flood and erosion. The outcome of this study can be used by decision-makers for sustainable watershed management and planning.
\end{abstract}

Keywords Morphometric $\cdot$ Watershed $\cdot$ Sub-watershed $\cdot$ Upper Benue $\cdot$ Streams

\section{Introduction}

Morphometry is "the quantitative measurement of the shapes and dimensions of Earth's landforms" (Clarke 1966). Morphometric analysis entails mathematical description and characteristics of the natural features which comprise aerial, linear, and relief within a watershed (Fenta et al. 2017). It is vital in hydrological examination especially in Pedology, groundwater management, and environmental assessment (Hajam et al. 2013). It offers a quantifiable description and understanding of the shape of the watershed as well as the initial slope, geological, structural control, rock hardness, and geomorphic history of the watershed (Strahler 1957). In

Caleb Akoji Odiji

odijic@yahoo.com

1 Department of Strategic Space Application, National Space Research and Development Agency, Airport Road, P.M.B. 437, Abuja, Nigeria

2 Department of Geosciences, Environment and Spatial Planning, University of Porto, Porto, Portugal a watershed, morphometric attributes are essential because they indicate the hydrological character of a watershed and are important in assessing the hydrologic response of a watershed (Withanage et al. 2015). Valuable information about the character of a watershed can be obtained via morphometric study (Dubey et al. 2015).

Additionally, analysis of watershed morphometry is crucial to the development of water and land resources and provides information that is helpful in flood risk control and knowledge on how physical features of the terrain aid the advancement of a watershed (Vandana 2013). Pophare and Balpande 2014 noted that analysis of a watershed using a morphometric parameter assists in the assessment of the changes and resource potential within a watershed. Quantification and prioritization of a watershed using morphometric parameters are essential for watershed planning base on the fact that it brings to the fore the characteristics of a watershed (Sukristiyanti et al. 2018). Quantitative assessment of landform properties were usually in the past done manually, which unfortunately was time-consuming as the landform properties have to be extracted from topographic maps. The

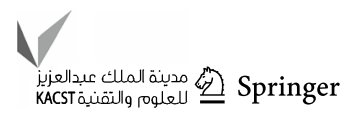


advent of computers and further advances in computer technology have been a game-changer that has made it possible for measuring and evaluating landforms of the earth's surface. Geographic Information Systems (GIS) and Remote Sensing have demonstrated to be an indispensable means for the interpretation and analysis of watershed morphometry.

Studies have shown the indispensability of geospatial technique in the morphometric study of a watershed. Mahala (2019), in his study, highlights the efficiency of remote sensing and geospatial tools in the understanding and demarcation of a River watershed in northern and eastern India. In another study by Venkatesh and Anshumali (2019) GIS was used to assess the morphometric properties of the Betwa River watershed in Central India. Mustafa et al. (2016) analyzed the morphometry of the Galagu valley watershed in Sudan to provide information about the inundation potential and hydrological attributes. Fenta et al. (2017) used the geospatial and statistical method to analytically quantify the morphometric parameters of Agula watershed in Ethiopia. Arabameri et al. (2020) in their study used digital elevation model (DEM) to evaluate the morphometric characteristics and prioritize sub-watersheds based on their susceptibility to erosion by water using a remote sensing-based data and GIS in Kalvari watershed, Iran. Findings from these studies revealed that morphometric analysis provided vital information about linear, areal, and relief characteristics of the watershed and the identification of erosion and flood-prone areas. Few studies have been carried out in Nigeria; Ajibade et al. (2010) in their study used topographic maps to evaluate the morphometric characteristics of Ogunpa and Ogbere Drainage Basins, Ibadan. It was observed that the data and method adopted in this study were not adequate. Another study carried out by Bunmi et al. (2017) used DEM to analyze the morphometry of Asa and Oyun River Basins, North Central Nigeria. Ezeh and Mozie (2019) carried a morphometric analysis of Idemili Basin using geospatial techniques. Other studies include Salami et al. 2017; Taofik et al. 2017; and Oruonye et al. 2016. There are quite a few research gaps in this study. Firstly, the upper Benue River watershed is one of the major hydrological watersheds in Nigeria. However, there is a dearth of detailed information about the morphometric characteristics of the watershed. Secondly, most studies carried out in Nigeria did not factor in the aspect of watershed prioritization. The economy and health of the ecosystem of any nation are intrinsically linked to the condition of the watershed as far as land degradation and flooding is a concern. A poorly managed watershed normally results in an alteration of the hydrological processes and degradation of the ecosystem (Forest Management Bureau 2011). Therefore, it is essential to evaluate and prioritize the upper Benue River watershed to understand its features, components and behaviour and for the management of natural resources for sustainable development.
This study aims to evaluate the morphometric parameters of the upper Benue River watershed. The objectives of this study are to: (1) delineate the sub-watershed, (2) assess the linear, areal, and relief parameters of the sub-watershed and (3) prioritize the sub-watershed using GIS and Remote Sensing based data. The study will enhance better and sustainable watershed management and improve land use planning, water conservation, and resource management.

\section{Materials and methods}

\section{Description of the study area}

The upper Benue River watershed is located between latitude $6^{\circ} 29^{\prime} \mathrm{N}$ to $11^{\circ} 46^{\prime} \mathrm{N}$ and longitude $8^{\circ} 55^{\prime} \mathrm{E}$ to $13^{\circ} 30^{\prime} \mathrm{E}$. The watershed extends $532 \mathrm{~km}$ from north to south and $480 \mathrm{~km}$ from west to east. The watershed covers an area of 154,328.9 $\mathrm{km}^{2}$. Lake Chad Watershed bounds the upper Benue River watershed to the north, to the east and south by the Republic of Cameroon, and the west by Lower Benue and upper Niger watershed (Fig. 1). The major river in the watershed is the River Benue that has its origins in the Adamawa Plateau of Northern Cameroon and flows south-west to meet with River Niger in Lokoja. The River Benue is joined by its major tributaries; the Gongola River, the Mayo Kébbi, Taraba River, and River Katsina-Ala. The altitude of the watershed ranges from 80 to $2034 \mathrm{~m}$ with a mean elevation of $400 \mathrm{~m}$. According to the Koppen climate classification, the upper Benue River watershed is characterized by a tropical savannah climate in the south and middle and warm semi-arid climate in the north. The watershed is marked by these agro-ecological zones; mid-latitude zone, derived savannah, northern guinea savannah, southern guinea savannah, and Sahel savannah. The mean annual rainfall ranges between 700 and $1200 \mathrm{~mm}$ and an average annual temperature ranges from 24 to $27{ }^{\circ} \mathrm{C}$ (Ishaku et al. 2015).

\section{Data sources and methods}

The main data used for this study was a $30 \mathrm{~m}$ resolution Shuttle Radar Topographic Mission (SRTM) Digital Elevation Model (DEM) obtained from https://earthexplorer. usgs.gov/ (Table 1). The DEM was used to extract stream network, slopes, and terrain features. Figure 2 shows the flowchart of this study.

\section{Method of data processing}

\section{Database creation and digitizing}

The topographic and hydrological maps were scanned and imported into the ArcGIS 10.5 application software. The 

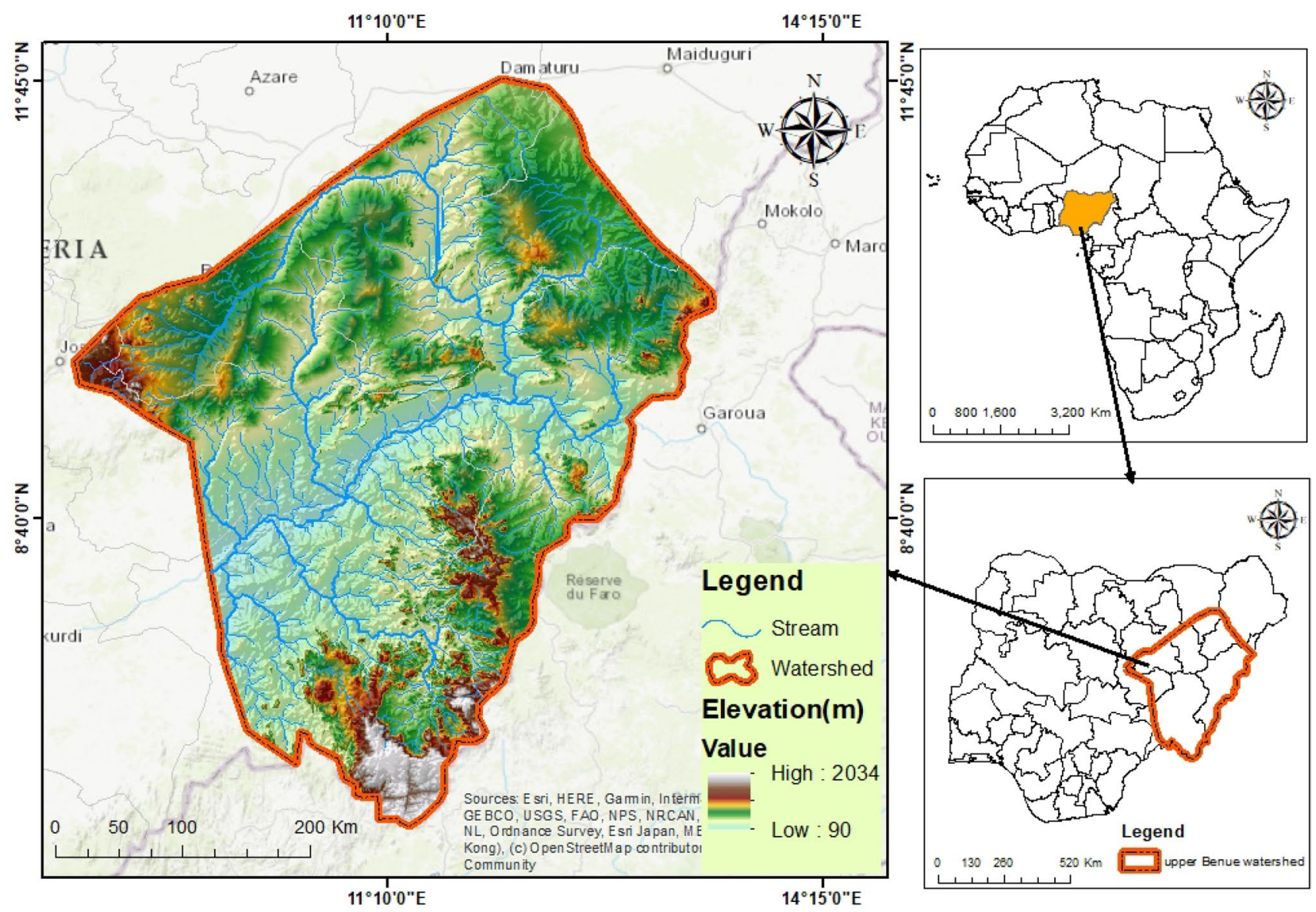

Fig. 1 Location map of the upper benue river watershed

Table 1 Data sources

\begin{tabular}{|c|c|c|c|c|}
\hline Data & Resolution/scale & Data & Scene ID/ Sheet no & Source \\
\hline SRTM DEM & $30 \mathrm{~m}$ & 2016 & n05_e011—n11_e012 & https://earthexplorer.usgs.gov/ \\
\hline Topographic Map & $1: 250,000$ & & $\begin{array}{l}34,35,36,37,38,45 \\
46,47,48,55,56 \text { and } \\
57\end{array}$ & $\begin{array}{l}\text { Office of the Surveyor- } \\
\text { General of the Federation } \\
\text { (OSGOF) }\end{array}$ \\
\hline Hydrological Map & $1: 6,000,000$ & 2015 & & $\begin{array}{l}\text { Federal Ministry of Water } \\
\text { Resources (FMWR) }\end{array}$ \\
\hline
\end{tabular}

dataset was georeferenced and projected using the Projected Coordinate System (PCS) (WGS 1984, Zone 33 N). Features particularly rivers and watershed boundary were extracted by visual image interpretation and on-screen digitizing from the maps.

\section{Generating stream network}

The stream network of the watershed was generated from the DEM by utilizing the ArcGIS 10.5 hydrology tool. The DEM was filled to reduce errors. Flow accumulation and direction were used to generate streams and then ranked according to the Strahler method of stream ordering (Mayomi et al. 2019; Das and Pardeshi 2018; Hajam et al. 2013). The stream network derivation was established on a threshold accumulation value of 500 which means that each cell of the drainage network has a minimum of 500 contributing cells resulting in a less dense stream network than lower threshold value depending on the size of the watershed (Chang 2014; Arabameri et al. 2020) and ideally the resulting stream network correspond to what is obtained on high-resolution topographic and field mapping (Tarboton 1997). 


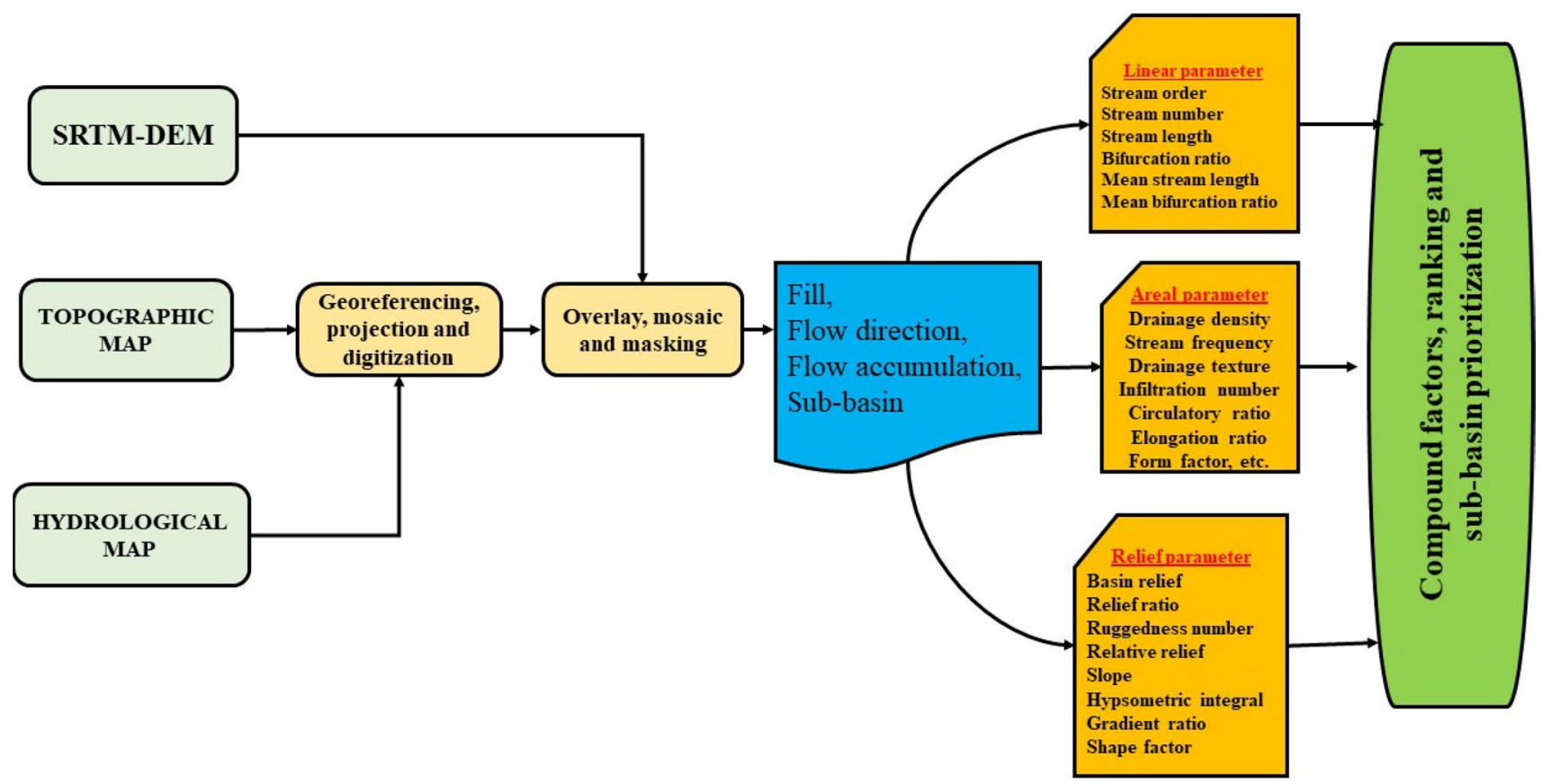

Fig. 2 Flow chart for the study

\section{Delineation of sub-watersheds}

The 'burn-in' function in ArcSWAT was used to delineate the sub-watershed of the study area. The DEM was imported into the Soil and Water Assessment Tool (SWAT) where the stream network data was overlaid on it to define the boundary of the sub-watershed through the pour point. This technique works by overlaying the DEM with the stream data to outline the location of the stream network and also to aid the processing of the DEM by filling the sink, determining the flow accumulation and direction. "Burn-in" is an algorithm that was proposed in the University of Texas by Maidment (Luo et al. 2011). ArcGIS 10.5 zonal statistics as table tool was used to compute the area, length, perimeter, minimum elevation, maximum elevation and mean elevation of each sub-watershed.

\section{Topographic wetness index (TWI)}

The TWI is used to evaluate the potentials of flow intensity and accumulation. It was proposed by Beven and Kirkby (1979). The TWI is also known as Topographic Moisture Index; it describes the influence of topography on the locality and extent of saturated source areas of runoff generation (Wilson and Gallant 2000). The TWI of the watershed was derived from DEM using a raster calculator in ArcGIS 10.5. Higher values are wetter and the lower values are drier. TWI is calculated as:
$T W I=\operatorname{int}\left(\frac{\text { Catchment Area }}{\tan B}\right)$

where $\tan B=$ slope in degree.

\section{Morphometric analysis of drainage systems}

A drainage system is composed of numbers and lengths of stream and tributaries of different sizes of orders regardless of their pattern (Horton 1945). The goal of the morphometric analysis is to evaluate the features of the upper Benue River watershed. Table 2 shows the following analysis carried out: linear, relief, and area aspect:

\section{Sub-watershed prioritization}

Prioritization of sub-watershed is strategic to water management and vulnerability assessment of a watershed to flood and soil erosion. In prioritizing the sub-watersheds, the study adopted the approach of Chandniha and Kansal 2017; Waiyasusri and Chotpantarat 2020 in prioritizing subwatershed based on the morphometric analysis. The compound factor was obtained by averaging the variables in each sub-watershed. The compound factor in each sub-watershed is ranked from the lowest value to the highest value starting with the linear variable. The factors are categorized into five classes: very low, low, medium, high, and very high priority. The compound values were calculated by adding all the parameters and dividing them by the number of parameters. 


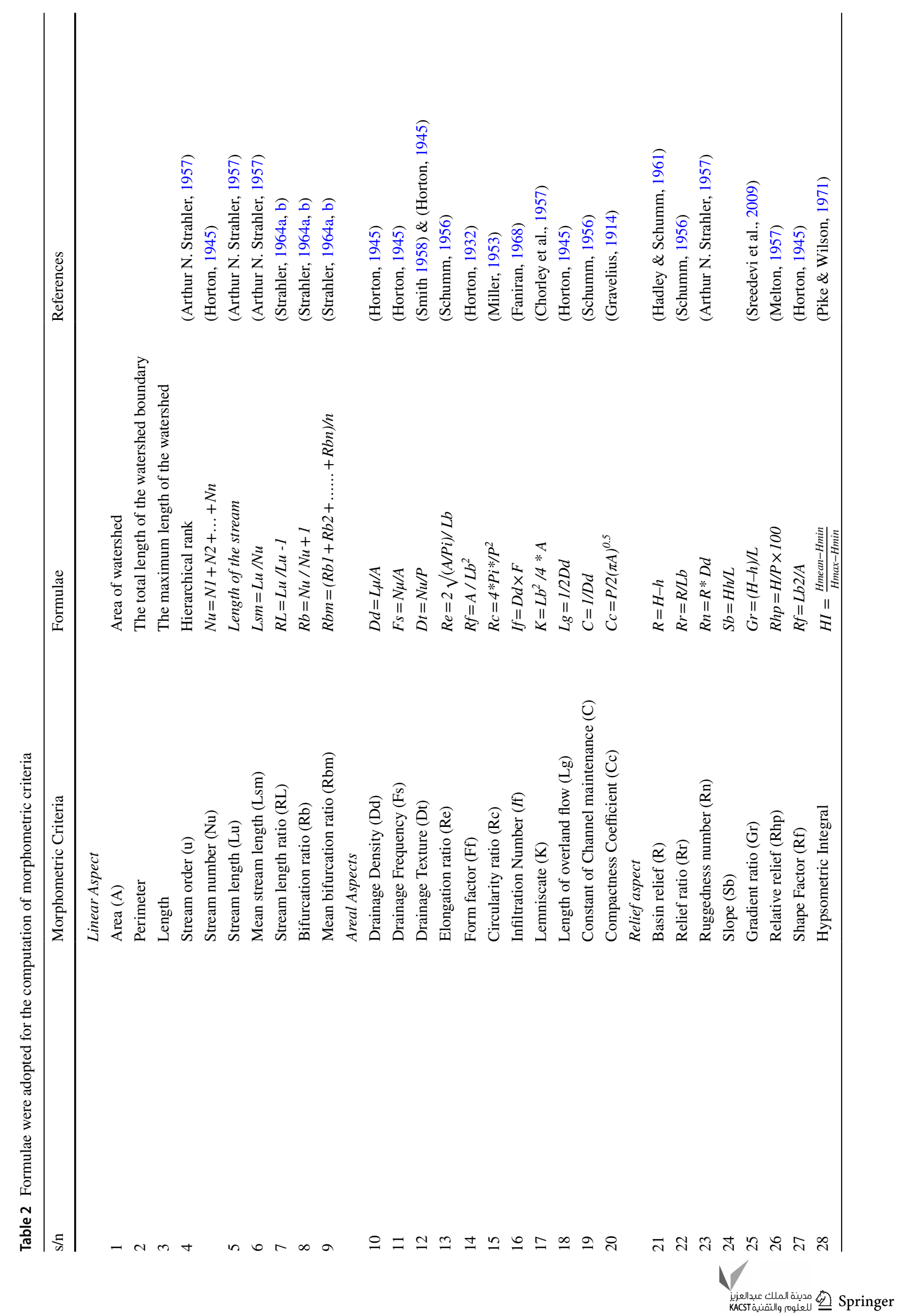


High priority value was assigned to sub-watersheds with the lowest compound factor.

\section{Hypsometry}

It is the measurement of height relative to sea level (Langbein 1947) and it is a reflection of the connection between the altitude and watershed area (Strahler 1952). To identify the stages of geomorphic development in the watershed, the hypsometric analysis was carried out using DEM. Hypsometric curves and hypsometric integral were produced to evaluate the health of the watershed. Several studies have adopted the geospatial approach for hypsometric analysis (Singh 2009; Sharma et al., 2010; Biswas et al., 2014). Hypsometric curves were characterized by calculating the hypsometric integral (HI) using the equation as proposed by (Pike and Wilson 1971):

$\mathrm{HI}=\frac{\text { Mean Elevation }- \text { Minimum Elevation }}{\text { Maximum Elevation }- \text { Minimum Elevation }}$

The HI ranges from 0 to 1 , if the $\mathrm{HI}$ value ranges from 0.6 to 1 ; it implies a youthful state; if the HI value ranges from 0.35 to 0.60 , it indicates a mature stage; and if the HI value is less than 0.35 , then it indicates old stage (Pike and Wilson 1971; Softa et al. 2018;). The zonal statistics tool in ArcGIS 10.5 was used to produce mean HI value for each of the sub-watershed.

\section{Asymmetry factor (AF)}

The AF is used to estimate the general tectonic tilting within the drainage landscape and the direction of tilting
Fig. 3 Sub-watershed of the upper Benue River watershed

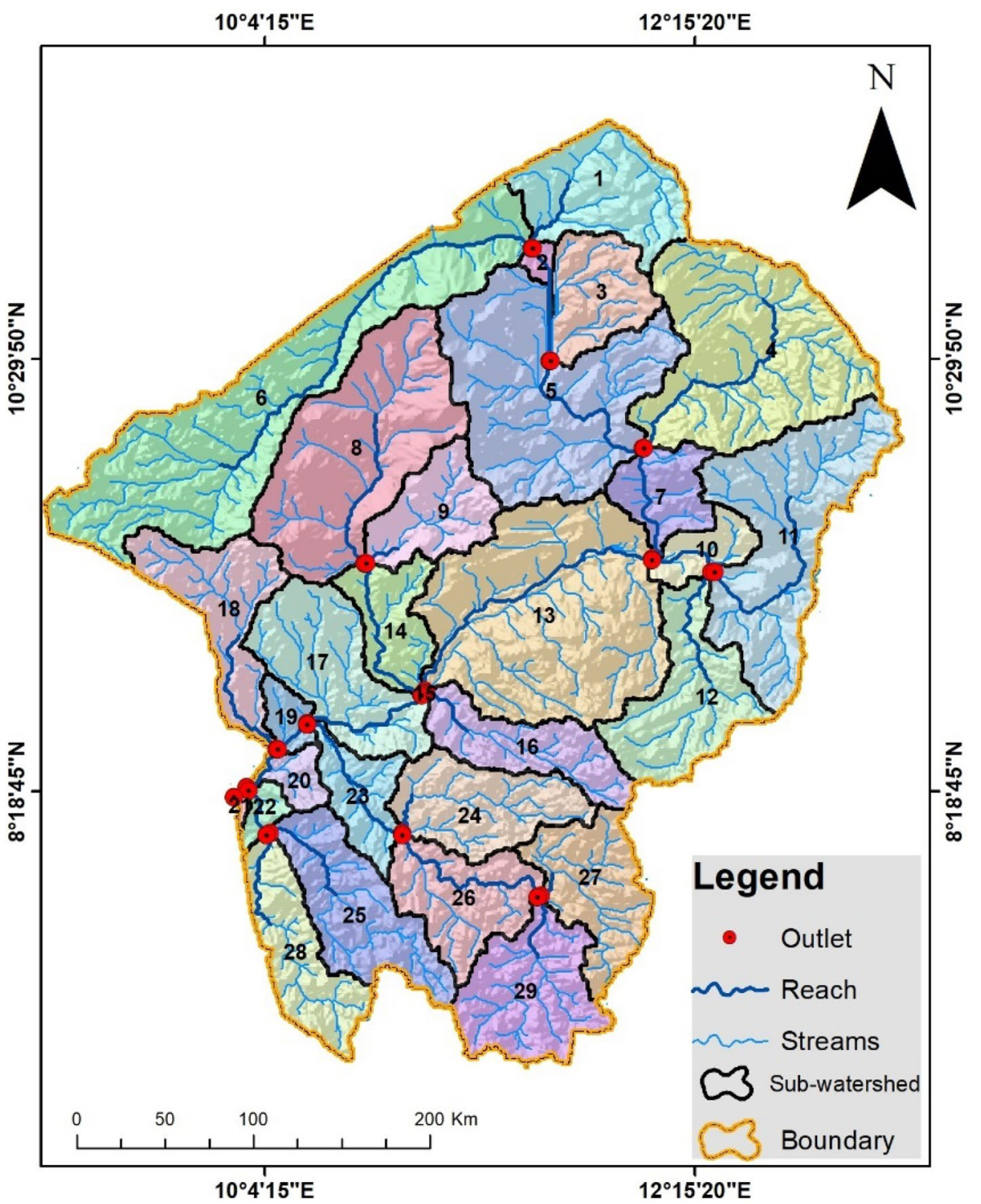


due to local or regional tectonic deformation (Keller and Pinter 2002; Kale et al. 2014). The Gardner et al. 1987 equation was used to calculate the AF.

$\mathrm{AF}=100\left(\frac{A r}{A t}\right)$

where $\mathrm{Ar}=$ area of the right (facing downstream of the trunk stream) and $\mathrm{At}=$ total area of the drainage basin. Hare and Gardner (1985) noted that the AF above or below 50 may result from basin tilting, due to either active tectonics or structural controlled differential erosion. If the basin tilts towards the downstream left side, it indicates that the AF value is greater than $50 \%$. On the other hand, if $\mathrm{AF}$ value is less than $50 \%$, it indicates that the basin has tilted towards the downstream right side.
Results and discussion

\section{Delineation of sub-watershed}

Using the "Burn-in" function in ArcSWAT, the stream network was overlaid onto the DEM to define the boundaries of the sub-watershed of the area via the pour points. The result shows that the watershed is divided into 29 separate sub-watersheds according to the distribution of the stream network as shown in Fig. 3. Each sub-watershed has an outlet and a reach. The outlet is like a passage where all streams within a sub-watershed flow into another. The subwatershed area is the area where all streams flow emerging from the area is drained through a sole passage. It would be ideal to have gauge stations and dams at every outlet in sub-watershed to record the volume of discharge. The size of the sub-watershed ranges from 6.78 to $14,825.7$ $\mathrm{km}^{2}$. The largest sub-watershed is number 6 that covers an

Table 3 Characteristics of sub-watershed

\begin{tabular}{|c|c|c|c|c|c|c|c|}
\hline Sub-watershed & Min elevation & Max elevation & Mean elevation & Area $\left(\mathrm{km}^{2}\right)$ & $\%$ area coverage & Length $(\mathrm{km})$ & Perimeter \\
\hline 1 & 257 & 687 & 393.35 & 5090.25 & 3.58 & 167.2 & 436.1 \\
\hline 2 & 241 & 470 & 285.37 & 403.72 & 0.28 & 39.6 & 183.1 \\
\hline 3 & 240 & 823 & 376.54 & 3363.15 & 2.37 & 132.2 & 305.7 \\
\hline 4 & 182 & 1054 & 484.71 & $11,219.42$ & 7.89 & 262.0 & 638.4 \\
\hline 5 & 182 & 891 & 396.84 & $11,343.11$ & 7.98 & 263.6 & 722.6 \\
\hline 6 & 258 & 1612 & 580.61 & $14,825.69$ & 10.43 & 307.0 & 1101.6 \\
\hline 7 & 143 & 859 & 316.72 & 2439.06 & 1.72 & 110.1 & 310.5 \\
\hline 8 & 189 & 857 & 413.95 & $10,240.81$ & 7.21 & 248.8 & 612.4 \\
\hline 9 & 193 & 879 & 384.50 & 3366.05 & 2.37 & 132.2 & 359.0 \\
\hline 10 & 141 & 558 & 222.43 & 1576.22 & 1.11 & 86.0 & 236.1 \\
\hline 11 & 150 & 1455 & 376.17 & 9229.47 & 6.49 & 234.5 & 736.3 \\
\hline 12 & 152 & 1486 & 439.14 & 5336.07 & 3.75 & 171.8 & 542.3 \\
\hline 13 & 113 & 1362 & 304.08 & $14,303.60$ & 10.07 & 300.7 & 708.0 \\
\hline 14 & 114 & 768 & 204.89 & 2771.77 & 1.95 & 118.4 & 366.1 \\
\hline 15 & 114 & 144 & 119.75 & 6.92 & 0.005 & 4.0 & 14.9 \\
\hline 16 & 114 & 1571 & 447.57 & 3733.15 & 2.63 & 140.2 & 447.3 \\
\hline 17 & 102 & 530 & 185.03 & 5697.10 & 4.01 & 178.2 & 482.9 \\
\hline 18 & 103 & 1514 & 425.83 & 4598.72 & 3.24 & 157.9 & 542.7 \\
\hline 19 & 97 & 194 & 129.06 & 897.46 & 0.63 & 62.4 & 187.6 \\
\hline 20 & 94 & 206 & 128.05 & 996.56 & 0.70 & 66.2 & 200.4 \\
\hline 21 & 90 & 154 & 113.56 & 131.75 & 0.09 & 21.0 & 79.8 \\
\hline 22 & 96 & 174 & 123.34 & 641.48 & 0.45 & 51.6 & 146.7 \\
\hline 23 & 102 & 576 & 166.12 & 2363.98 & 1.66 & 108.2 & 354.5 \\
\hline 24 & 142 & 1170 & 308.52 & 4604.26 & 3.24 & 158.0 & 428.6 \\
\hline 25 & 102 & 1604 & 367.40 & 5173.54 & 3.64 & 168.7 & 504.5 \\
\hline 26 & 143 & 1300 & 414.39 & 4251.28 & 2.99 & 149.7 & 411.8 \\
\hline 27 & 249 & 1900 & 638.60 & 4308.39 & 3.03 & 150.7 & 456.3 \\
\hline 28 & 101 & 1088 & 209.71 & 4002.66 & 2.82 & 146.0 & 435.8 \\
\hline 29 & 249 & 1964 & 748.20 & 5192.36 & 3.65 & 169.1 & 459.8 \\
\hline
\end{tabular}


Fig. 4 Stream order of upper Benue River watershed

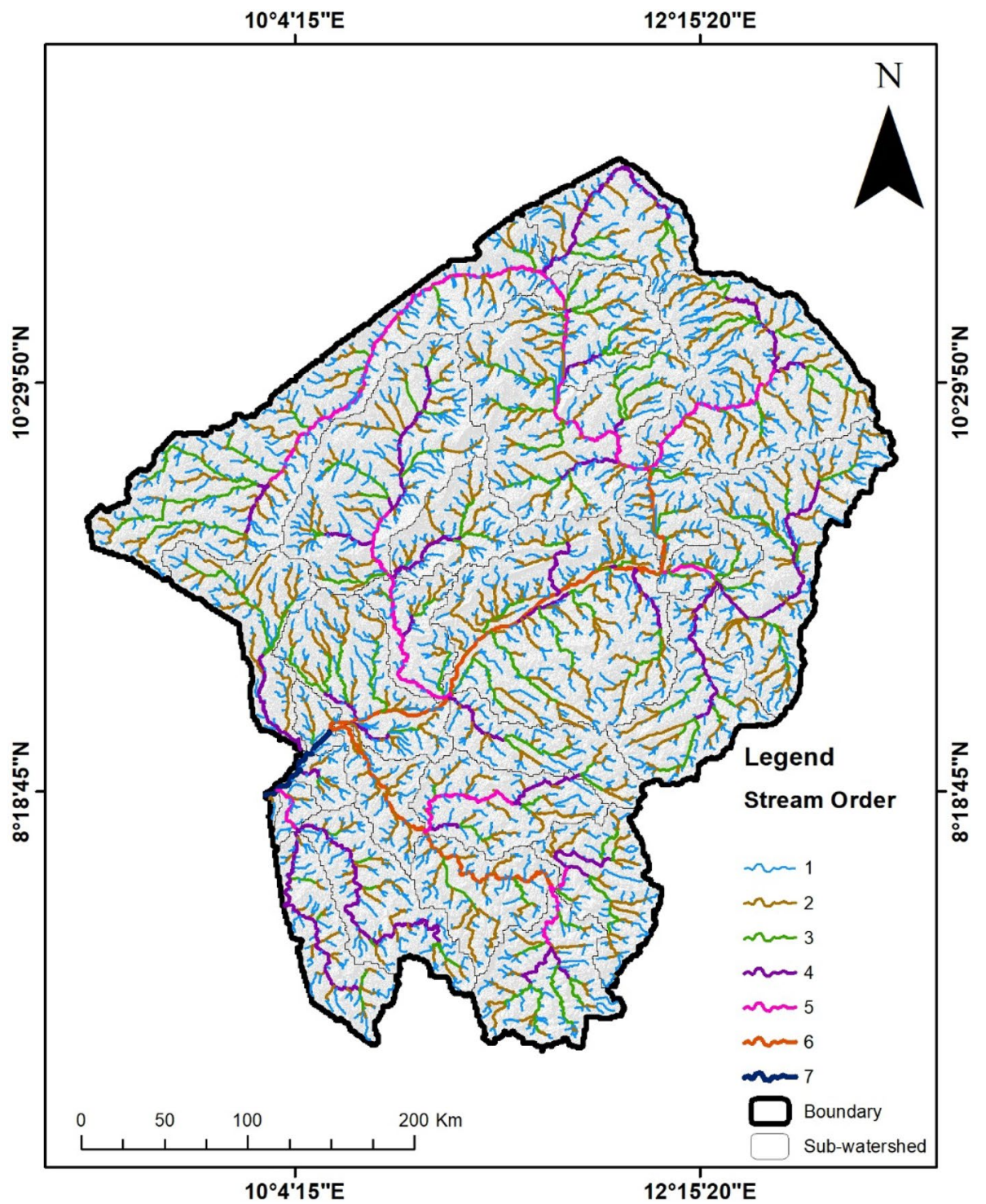

Table 4 Summary of Linear morphometric parameters of Upper Benue River Watershed

\begin{tabular}{|c|c|c|c|c|c|c|c|c|}
\hline \multirow{2}{*}{$\begin{array}{l}\text { Stream } \\
\text { order } \\
1\end{array}$} & \multirow{2}{*}{$\begin{array}{l}\text { Number } \\
\text { of streams } \\
(\mathrm{Nu})\end{array}$} & \multirow{2}{*}{$\begin{array}{l}\text { Total stream } \\
\text { length }(\mathrm{km}) \\
(\mathrm{Lu})\end{array}$} & \multicolumn{2}{|c|}{$\begin{array}{l}\text { Mean stream } \\
\text { length }(\mathrm{Km})\end{array}$} & \multirow{2}{*}{$\begin{array}{l}\text { Cumulative mean } \\
\text { stream length } \\
(\mathrm{Km})\end{array}$} & $\log \mathrm{Nu}$ & \multirow{2}{*}{$\begin{array}{l}\text { Log } \\
\mathrm{Lu} \\
4.18\end{array}$} & \multirow[t]{2}{*}{$\begin{array}{l}\text { Length } \\
\text { ratio }\end{array}$} \\
\hline & & & & & & 3.44 & & \\
\hline 2 & 1295 & 7510.74 & 11.92 & & 17.72 & 3.11 & 3.88 & 0.46 \\
\hline 3 & 680 & 3703.98 & 5.8 & & 23.22 & 2.83 & 3.57 & 0.53 \\
\hline 4 & 42 & 1922.29 & 5.5 & & 69.02 & 1.62 & 3.28 & 0.06 \\
\hline 5 & 8 & 1019.25 & 45.8 & & 196.42 & 0.90 & 3.00 & 0.19 \\
\hline 6 & 4 & 587.08 & 127.4 & & 269.72 & 0.60 & 2.77 & 0.5 \\
\hline 7 & 1 & 62.7 & 73.3 & & 332.42 & 0 & 1.80 & 0.25 \\
\hline Total & 4821 & $30,232.84$ & 269.72 & & 920.44 & & & \\
\hline \multicolumn{9}{|c|}{ Bifurcation Ratio } \\
\hline $\begin{array}{l}\text { 1st order/ } \\
2 \text { nd order }\end{array}$ & $\begin{array}{l}\text { 2ndorder/ } \\
\text { 3rdorder }\end{array}$ & $\begin{array}{l}\text { 3rdorder/ } \\
\text { 4thorder }\end{array}$ & $\begin{array}{l}\text { 4thorder/ } \\
\text { 5thorder }\end{array}$ & $\begin{array}{l}5 \text { th order/ 6th } \\
\text { order }\end{array}$ & 6 th order/ 7 th order & & & \\
\hline 2.16 & 1.90 & 16.2 & 5.25 & 2 & 4 & 4.5 & & \\
\hline
\end{tabular}


area of $14,825.7 \mathrm{~km}^{2}(10.43 \%)$. sub-watershed number 15 is the smallest which covers an area of $6.78 \mathrm{~km}^{2}(0.005 \%)$ as shown in Table 3.

\section{Morphometric analysis of Upper Benue River Watershed}

\section{Linear parameter}

\section{Stream order $(\mathrm{u})$}

Strahler's 1964a, b ordering system was adopted for this study due to its simplicity and has been used in several studies (Dubey et al. 2015; Mustafa et al. 2016; Resmi et al. 2019; Asfaw and Workineh 2019; Arabameri et al. 2020). The result revealed that the Upper Benue River Watershed has 4821 streams connected with seven stream orders as seen in Fig. 4 and Table 4. Usually, the highest stream order existing in the watershed is regarded as the order of the watershed (Umrikar 2017). The Upper Benue River Watershed may, therefore, be described as a seventh-order watershed system. The 1 st stream order is the maximum followed by the 2 nd stream order then the $3 \mathrm{rd}, 4 \mathrm{th}, 5 \mathrm{th}, 6 \mathrm{th}$, and 7 th stream order in decreasing pattern as shown in Fig. 5a. Higher stream order is linked with the greater ejection of water, sediment, and nutrient (Hajam et al. 2013). The drainage pattern of the upper Benue River watershed was identified to be dendritic
Fig. 5 a Stream length vs stream order, b Log of stream number vs stream order, c Mean stream length vs stream order
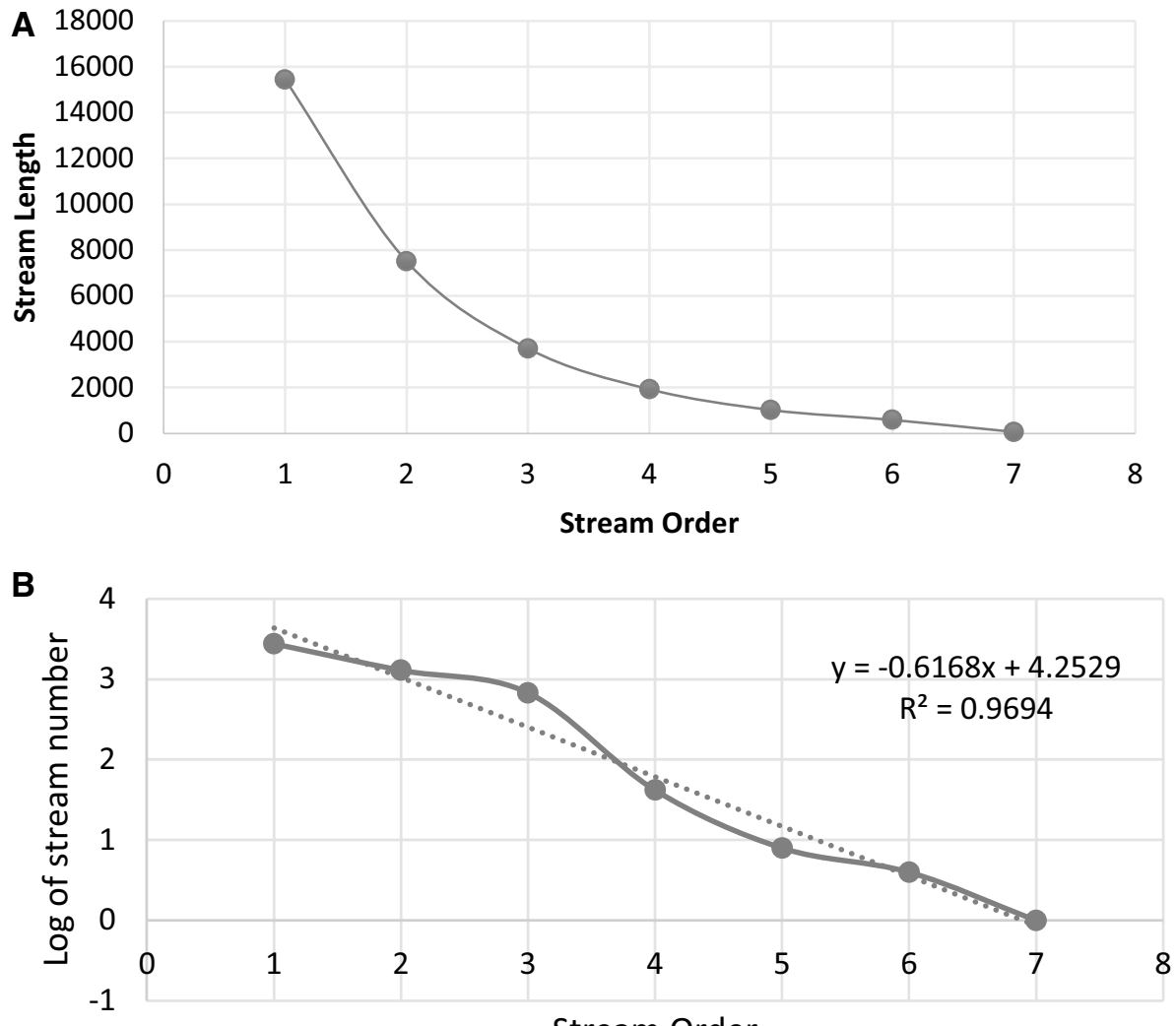

Stream Order

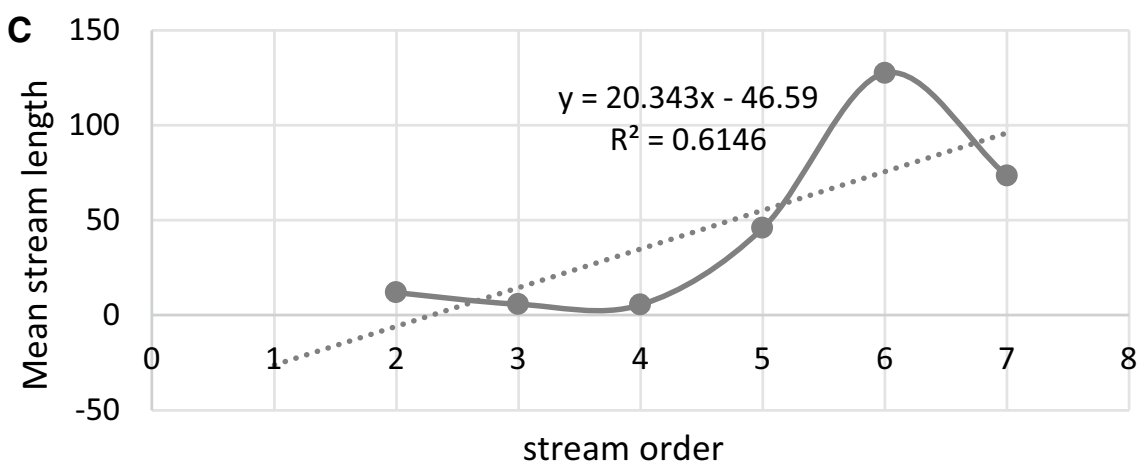

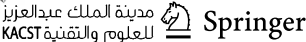


developed due to variation like the terrain where the rivers flow and the underlying rock structure (Ritter et al. 2002; Asfaw and Workineh 2019). The first stream orders are usually numerous and short and they emanate from the hilly and ruggedly mountainous landscape of the watershed, while the seventh stream order which is the principal river of the watershed is found in the plain or valley. It was observed just like most studies conducted that as the stream order increases, the number of streams decreases, and this is attributed to the structural and physiographic condition of the area (Resmi et al. 2019).

\section{Stream number $(\mathrm{Nu})$}

The number of streams of various orders was counted from the attribute table of the stream layers in ArcGIS 10.5. The count revealed that 4821 streams were extracted out of which 2791 are 1st order streams, 1295 are 2 nd order streams, 680 are 3 rd order streams, 42 are 4 th order streams, 8 are 5th order streams, 4 are 6th order streams and 1 is 7 th order stream as seen in Table 4. This means that the number of streams usually decreases in geometric progression as the stream order increases (Horton 1945). This confirms the findings of Pophare and Balpande (2014) that the difference in rock structure is responsible for the different stream order. The 1st and 2nd stream orders, respectively, constitute $57.89 \%$ and $26.87 \%$ of the watershed originating from the mountains and hills with a steep/moderate slope and are usually seasonal. The $3 \mathrm{rd}$ and 4 th stream order constitutes $14.10 \%$ and $0.87 \%$ of the watershed reflecting morphological changes. While $0.17 \%, 0.08 \%$, and $0.02 \%$ represent streams of the 5th, 6th, and 7th order mostly found in the plains of the watershed with loads of sediments and high erosion attributes. Sub-watershed 4 has the highest with 318 streams and sub-watershed 15 with 2 streams (Table 5a and b). Dams and water harvesting structures are recommended in regions with 5th, 6th, and 7th stream orders for irrigation, electricity generation, and improve soil moisture. Horton (1945) laws of stream numbers state that "the number of stream segments of each order forms an inverse geometric sequence when plotted against the order". He opined that most stream networks indicate a linear relationship, with a small abnormality from a straight line. Regression analysis was also applied to validate the data and to obtain further precise results to show possible relationships and measure the strength of the relationship. $\mathrm{R}^{2}$ values indicate that the best-fitted model to illustrate the relation of stream order and stream number. The $\mathrm{R}^{2}$ value of 0.9694 shows that there is a strong correlation between the stream number and stream order (Fig. 5b).

\section{Stream length (Lu)}

The total length of all stream sections in the watershed is $30232.84 \mathrm{~km}^{2}$. The $1^{\text {st }}$ order streams have a cumulative stream length of over $15,438.59 \mathrm{~km}(51.1 \%)$ while the $7^{\text {th }}$ order stream has a total stream length of $62.7 \mathrm{~km}(0.21 \%)$ as seen in Table 4. The total length of stream segments is more in the case of first-order streams and decreases with an increase in the stream order (Table 5a and 5b). This is attributed to streams flowing from high altitude, variation in relief, moderately steep slope, and probable uplift across the watershed (Horton 1945).

\section{Mean stream length (Lsm)}

The mean stream length is a typical property connected to the stream network component and its related watershed surface (Strahler 1964a, b). As the stream order increases so do the mean stream length. There are, however, exceptions in some sub-watershed where a higher stream order reveals a low mean stream length which can be attributed to areal differentiation and terrain (Table 5a and 5b). Some studies reported this irregularity (Pophare and Balpande 2014; Vittala et al. 2004). Figure 5c shows mean stream length plotted against stream order, and it shows that there is a negative relationship between mean stream length and stream order. It was observed that the mean stream length of the 6th stream order is higher than the 7th stream order, a behaviour which according to Singh and Singh (1997) is due to terrain that is shaped by high relief and reasonably steep slope (Table 4).

\section{Stream length ratio $(\mathbf{R L})$}

The stream length ratio has a vital link with the surface flow and discharge and erosion stage of the watershed. The values of the stream length ratio in the watershed range from 0.06 to 0.53 , which is attributed to the slope and topographic condition of the watershed (Table 4). This asserts the studies carried out by Mahala 2019; Resmi et al. 2019and Pande and Moharir 2017 that differences in the stream length ratio are a result of the slope and nature of the topography. Similarly, the values of stream length ratio also indicate late youth to the early matured phase of landform development (Singh and Singh 1997, Vittala et al. 2004).

\section{Bifurcation rRatio $(\mathbf{R b})$ and mean bifurcation ratio (Rbm)}

The bifurcation ratio values for the upper Benue River watershed vary from 2.16 to 16.2 as shown in Table 4 . Streams of the $3^{\text {rd }}$ and $4^{\text {th }}$ order have the highest bifurcation ratio (16.2) which implies high surface runoff and discharge due 
Table 5 a Linear morphometric parameters of Upper Benue River Watershed, b linear morphometric parameters of Upper Benue River Watershed

\begin{tabular}{|c|c|c|c|c|c|c|c|c|c|c|c|c|c|c|}
\hline \multirow[t]{2}{*}{ Parameters } & \multicolumn{14}{|c|}{ Sub-watershed } \\
\hline & 1 & 2 & 3 & 4 & 5 & 6 & 7 & 8 & 9 & 10 & 11 & 12 & 13 & 14 \\
\hline \multicolumn{15}{|l|}{ Stream Order } \\
\hline 1 & 97 & 14 & 70 & 203 & 198 & 142 & 50 & 145 & 73 & 41 & 184 & 60 & 121 & 65 \\
\hline 2 & 17 & 4 & 34 & 103 & 53 & 50 & 11 & 41 & 19 & 11 & 34 & 24 & 60 & 9 \\
\hline 3 & 4 & 3 & 15 & 9 & 11 & 10 & 4 & 13 & 5 & 4 & 10 & 6 & 18 & 4 \\
\hline 4 & 1 & 2 & 2 & 2 & 2 & 3 & 1 & 3 & 1 & 3 & 1 & 1 & 5 & 2 \\
\hline 5 & 0 & 1 & 1 & 1 & 1 & 1 & 0 & 1 & 0 & 1 & 0 & 0 & 2 & 1 \\
\hline 6 & 0 & 0 & 0 & 0 & 0 & 0 & 0 & 0 & 0 & 0 & 0 & 0 & 1 & 0 \\
\hline 7 & 0 & 0 & 0 & 0 & 0 & 0 & 0 & 0 & 0 & 0 & 0 & 0 & 0 & 0 \\
\hline Total & 119 & 24 & 122 & 318 & 265 & 206 & 66 & 203 & 98 & 60 & 229 & 91 & 206 & 81 \\
\hline \multicolumn{15}{|l|}{ Stream Length(km) } \\
\hline 1st order & 528 & 45 & 412 & 1249 & 1232 & 1571 & 345 & 1198 & 364 & 208 & 1043 & 540 & 1516 & 301 \\
\hline 2nd order & 249 & 34 & 180 & 710 & 578 & 620 & 132 & 469 & 209 & 87 & 565 & 242 & 967 & 92 \\
\hline 3rd order & 110 & 6 & 131 & 219 & 421 & 445 & 59 & 252 & 73 & 72 & 218 & 149 & 407 & 69 \\
\hline 4 th order & 161 & 1 & 39 & 106 & 60 & 56 & 0 & 158 & 69 & 14 & 166 & 122 & 146 & 18 \\
\hline 5 th order & 0 & 62 & 10 & 134 & 119 & 270 & 73 & 53 & 0 & 42 & & 0 & 4 & 119 \\
\hline 6 th order & 0 & 0 & 0 & 0 & 0 & 0 & 0 & 0 & 0 & 0 & 0 & 0 & 179 & 0 \\
\hline 7 th order & 0 & 0 & 0 & 0 & 0 & 0 & 0 & 0 & 0 & 0 & 0 & 0 & 0 & 0 \\
\hline Total & 1047 & 147 & 772 & 2418 & 2409 & 2962 & 609 & 2129 & 715 & 423 & 1993 & 1053 & 3219 & 599 \\
\hline \multicolumn{15}{|l|}{ Bifurcation ratio } \\
\hline $1 / 2$ & 5.7 & 3.5 & 2.1 & 1.9 & 3.7 & 2.8 & 4.5 & 3.5 & 3.8 & 3.7 & 5.4 & 2.5 & 2.02 & 7.22 \\
\hline $2 / 3$ & 4.3 & 1.3 & 2.3 & 11.4 & 4.8 & 5 & 2.75 & 3.2 & 3.8 & 2.8 & 3.4 & 4 & 3.33 & 2.25 \\
\hline $3 / 4$ & 4 & 1.5 & 7.5 & 4.5 & 5.5 & 3.3 & 4 & 4.3 & 5 & 1.3 & 10 & 6 & 3.6 & 2 \\
\hline $4 / 5$ & 0 & 2 & 2 & 2 & 2 & 3 & 0 & 3 & 0 & 3 & 0 & 0 & 2.5 & 2 \\
\hline $5 / 6$ & 0 & 0 & 0 & 0 & 0 & 0 & 0 & 0 & 0 & 0 & 0 & 0 & 2 & 0 \\
\hline $6 / 7$ & 0 & 0 & 0 & 0 & 0 & 0 & 0 & 0 & 0 & 0 & 0 & 0 & 0 & 0 \\
\hline Mean bifurcation ratio & 1.9 & 1.2 & 1.9 & 2.8 & 2.3 & 2.02 & 1.6 & 2 & 1.8 & 1.54 & 2.7 & 1.9 & 1.9 & 1.9 \\
\hline \multicolumn{15}{|l|}{ Mean stream length } \\
\hline 1st order & 5.4 & 3.2 & 5.9 & 6.2 & 6.2 & 11.1 & 6.9 & 8.26 & 4.99 & 5.07 & 5.6 & 9.001 & 12.5 & 4.63 \\
\hline 2nd order & 14.6 & 8.4 & 5.3 & 6.9 & 10.9 & 12.4 & 12 & 11.4 & 11 & 7.91 & 16.6 & 10.09 & 16.1 & 10.2 \\
\hline 3rd order & 27.4 & 2.1 & 8.7 & 24.3 & 38.2 & 44.5 & 14.75 & 19.4 & 14.5 & 18 & 21.8 & 24.82 & 22.6 & 17.2 \\
\hline 4th order & 160.7 & 0.25 & 19.5 & 52.9 & 30 & 18.7 & 0.26 & 52.8 & 69 & 4.67 & 165.9 & 121.9 & 29.2 & 9.11 \\
\hline 5 th order & 0 & 61.6 & 10.4 & 134.2 & 118.6 & 270 & 0 & 52.7 & 0 & 42 & 0 & 0 & 2.15 & 119 \\
\hline 6 th order & 0 & 0 & 0 & 0 & 0 & 0 & 0 & 0 & 0 & 0 & 0 & 0 & 179 & 0 \\
\hline 7 th order & 0 & 0 & 0 & 0 & 0 & 0 & 0 & 0 & 0 & 0 & 0 & 0 & 0 & 0 \\
\hline \multicolumn{15}{|l|}{ Stream length ratio } \\
\hline $2 \mathrm{nd} / 1 \mathrm{st}$ & 0.47 & 0.8 & 0.4 & 0.56 & 0.46 & 0.39 & 0.38 & 0.39 & 0.57 & 0.42 & 0.54 & 0.44 & 0.64 & 0.3 \\
\hline $3 \mathrm{rd} / 2 \mathrm{nd}$ & 0.4 & 0.21 & 0.7 & 0.3 & 0.7 & 0.72 & 0.44 & 0.54 & 0.35 & 0.83 & 0.38 & 0.61 & 0.42 & 0.75 \\
\hline $4 \mathrm{th} / 3 \mathrm{rd}$ & 1.5 & 0.08 & 0.3 & 0.5 & 0.14 & 0.13 & 0.004 & 0.63 & 0.95 & 0.19 & 0.76 & 0.81 & 0.36 & 0.26 \\
\hline 5 th/4th & 0 & 123.2 & 0.26 & 1.3 & 1.97 & 4.82 & 280.8 & 0.33 & 0 & 3 & 0 & 0 & 0.03 & 6.55 \\
\hline 6 th $/ 5$ th & 0 & 0 & 0 & 0 & 0 & 0 & 0 & 0 & 0 & 0 & 0 & 0 & 41.7 & 0 \\
\hline 7 th/6th & 0 & 0 & 0 & 0 & 0 & 0 & 0 & 0 & 0 & 0 & 0 & 0 & 0 & 0 \\
\hline
\end{tabular}


Table 5 (continued)

\begin{tabular}{|c|c|c|c|c|c|c|c|c|c|c|c|c|c|c|c|}
\hline \multicolumn{16}{|l|}{ Sub-watershed } \\
\hline Parameters & 15 & 16 & 17 & 18 & 19 & 20 & 21 & 22 & 23 & 24 & 25 & 26 & 27 & 28 & 29 \\
\hline \multicolumn{16}{|l|}{ Stream order } \\
\hline 1 & 2 & 65 & 97 & 72 & 19 & 19 & 4 & 16 & 47 & 82 & 92 & 67 & 62 & 53 & 82 \\
\hline 2 & 0 & 15 & 24 & 16 & 7 & 6 & 2 & 4 & 10 & 17 & 25 & 12 & 40 & 21 & 21 \\
\hline 3 & 0 & 4 & 7 & 2 & 5 & 4 & 0 & 2 & 1 & 5 & 6 & 3 & 23 & 5 & 7 \\
\hline 4 & 0 & 2 & 2 & 1 & 4 & 3 & 0 & 1 & 0 & 3 & 1 & 1 & 13 & 1 & 2 \\
\hline 5 & 0 & 1 & 1 & 0 & 2 & 1 & 0 & 0 & 0 & 2 & 0 & 0 & 1 & 0 & 1 \\
\hline 6 & 0 & 0 & 0 & 0 & 2 & 0 & 0 & 0 & 0 & 1 & 0 & 0 & 0 & 0 & 0 \\
\hline 7 & 0 & 0 & 0 & 0 & 1 & 0 & 0 & 0 & 0 & 0 & 0 & 0 & 0 & 0 & 0 \\
\hline Total & 2 & 87 & 131 & 91 & 40 & 33 & 6 & 23 & 58 & 110 & 124 & 83 & 139 & 80 & 113 \\
\hline \multicolumn{16}{|l|}{ Stream length $(\mathrm{km})$} \\
\hline 1st order & 4 & 389 & 675 & 437 & 127 & 119 & 16 & 83 & 258 & 423 & 583 & 391 & 436 & 426 & 521 \\
\hline 2 nd order & 0 & 174 & 359 & 301 & 40 & 45 & 15 & 21 & 154 & 228 & 237 & 226 & 239 & 155 & 188 \\
\hline 3rd order & 0 & 94 & 218 & 150 & 11 & 11 & 0 & 2 & 116 & 69 & 75 & 74 & 115 & 56 & 203 \\
\hline 4 th order & 0 & 56 & 64 & 90 & 11 & 19 & 0 & 36 & 0 & 81 & 210 & 7 & 77 & 152 & 65 \\
\hline 5 th order & 0 & 2 & 75 & 0 & 21 & 32 & 0 & 0 & 0 & 93 & 0 & 0 & 19 & 0 & 50 \\
\hline 6 th order & 0 & 0 & 0 & 0 & 54 & 0 & 0 & 0 & 0 & 1 & 0 & 0 & 0 & 0 & 0 \\
\hline 7 th order & 0 & 0 & 0 & 0 & 61 & 0 & 0 & 0 & 0 & 0 & 0 & 0 & 0 & 0 & 0 \\
\hline Total & 4 & 715 & 1391 & 978 & 325 & 226 & 31 & 142 & 528 & 895 & 1105 & 698 & 887 & 789 & 1027 \\
\hline \multicolumn{16}{|l|}{ Bifurcation ratio } \\
\hline $1 / 2$ & 0 & 4.33 & 4.04 & 4.5 & 2.7 & 3.17 & 2 & 4 & 4.7 & 4.82 & 3.68 & 5.58 & 1.55 & 2.52 & 3.9 \\
\hline $2 / 3$ & 0 & 3.75 & 3.43 & 8 & 1.4 & 1.5 & 0 & 2 & 10 & 3.4 & 4.17 & 4 & 1.74 & 4.2 & 3 \\
\hline $3 / 4$ & 0 & 2 & 3.5 & 2 & 1.3 & 1.3 & 0 & 2 & 0 & 1.67 & 6 & 3 & 1.77 & 5 & 3.5 \\
\hline $4 / 5$ & 0 & 2 & 2 & 0 & 2 & 3 & 0 & 0 & 0 & 1.5 & 0 & 0 & 13 & 0 & 2 \\
\hline $5 / 6$ & 0 & 0 & 0 & 0 & 1 & 0 & 0 & 0 & 0 & 2 & 0 & 0 & 0 & 0 & 0 \\
\hline $6 / 7$ & 0 & 0 & 0 & 0 & 2 & 0 & 0 & 0 & 0 & 0 & 0 & 0 & 0 & 0 & 0 \\
\hline Mean bifurcation ratio & 0 & 1.73 & 1.85 & 2.1 & 1.48 & 1.29 & 0.3 & 1.14 & 2.1 & 1.91 & 1.98 & 1.8 & 2.58 & 1.67 & 1.7 \\
\hline \multicolumn{16}{|l|}{ Mean stream length } \\
\hline 1 st order & 2 & 6 & 7 & 6.1 & 6.6 & 6.3 & 4 & 5.2 & 5.5 & 5.2 & 6.3 & 5.8 & 7.03 & 8.04 & 6.4 \\
\hline 2nd order & 0 & 11.6 & 15 & 19 & 5.7 & 7.5 & 7.5 & 5.3 & 15.4 & 13.4 & 9.5 & 18.8 & 6 & 7.4 & 9 \\
\hline 3rd order & 0 & 23.5 & 31.2 & 75 & 2.2 & 2.75 & 0 & 1 & 116 & 13.8 & 12.5 & 24.7 & 5.02 & 11.2 & 28.9 \\
\hline 4 th order & 0 & 27.9 & 32 & 90 & 2.85 & 6.33 & 0 & 36 & 0 & 26.8 & 210 & 6.75 & 5.94 & 152 & 32.4 \\
\hline 5 th order & 0 & 2.41 & 75.4 & 0 & 10.6 & 32 & 0 & 0 & 0 & 46.5 & 0 & 0 & 19.4 & 0 & 49.7 \\
\hline 6 th order & 0 & 0 & 0 & 0 & 27 & 0 & 0 & 0 & 0 & 0 & 0 & 0 & 0 & 0 & 0 \\
\hline 7 th order & 0 & 0 & 0 & 0 & 61 & 0 & 0 & 0 & 0 & 0 & 0 & 0 & 0 & 0 & 0 \\
\hline \multicolumn{16}{|l|}{ Stream length ratio } \\
\hline $2 \mathrm{nd} / 1 \mathrm{st}$ & & 0.45 & 0.53 & 0.7 & 0.32 & 0.38 & 0.9 & 0.25 & 0.6 & 0.54 & 0.41 & 0.58 & 0.55 & 0.36 & 0.36 \\
\hline $3 \mathrm{rd} / 2 \mathrm{nd}$ & 0 & 0.54 & 0.61 & 0.5 & 0.27 & 0.24 & 0 & 0.1 & 0.75 & 0.3 & 0.32 & 0.33 & 0.48 & 0.36 & 1.07 \\
\hline $4 \mathrm{th} / 3 \mathrm{rd}$ & 0 & 0.59 & 0.29 & 0.6 & 1.03 & 1.73 & 0 & 18 & 0 & 1.16 & 2.8 & 0.09 & 0.67 & 2.72 & 0.32 \\
\hline 5 th/4th & 0 & 0.04 & 1.18 & 0 & 1.85 & 1.68 & 0 & 0 & 0 & 1.16 & 0 & 0 & 0.25 & 0 & 0.76 \\
\hline 6 th/5th & 0 & 0 & 0 & 0 & 2.55 & 0 & 0 & 0 & 0 & 0 & 0 & 0 & 0 & 0 & 0 \\
\hline 7th/6th & 0 & 0 & 0 & 0 & 0 & 0 & 0 & 0 & 0 & 0 & 0 & 0 & 0 & 0 & 0 \\
\hline
\end{tabular}

to hilly and less resistant rock (Strahler 1964a, b). The mean bifurcation ratio of the upper Benue River watershed is 4.5 indicating that the drainage is not influenced by any structural disturbance (Das and Pardeshi 2018).

\section{Areal parameter}

\section{Drainage density $(D d)$}

The $D d$ is defined as the stream length per unit area (Horton 1945). The drainage density of any region is usually 


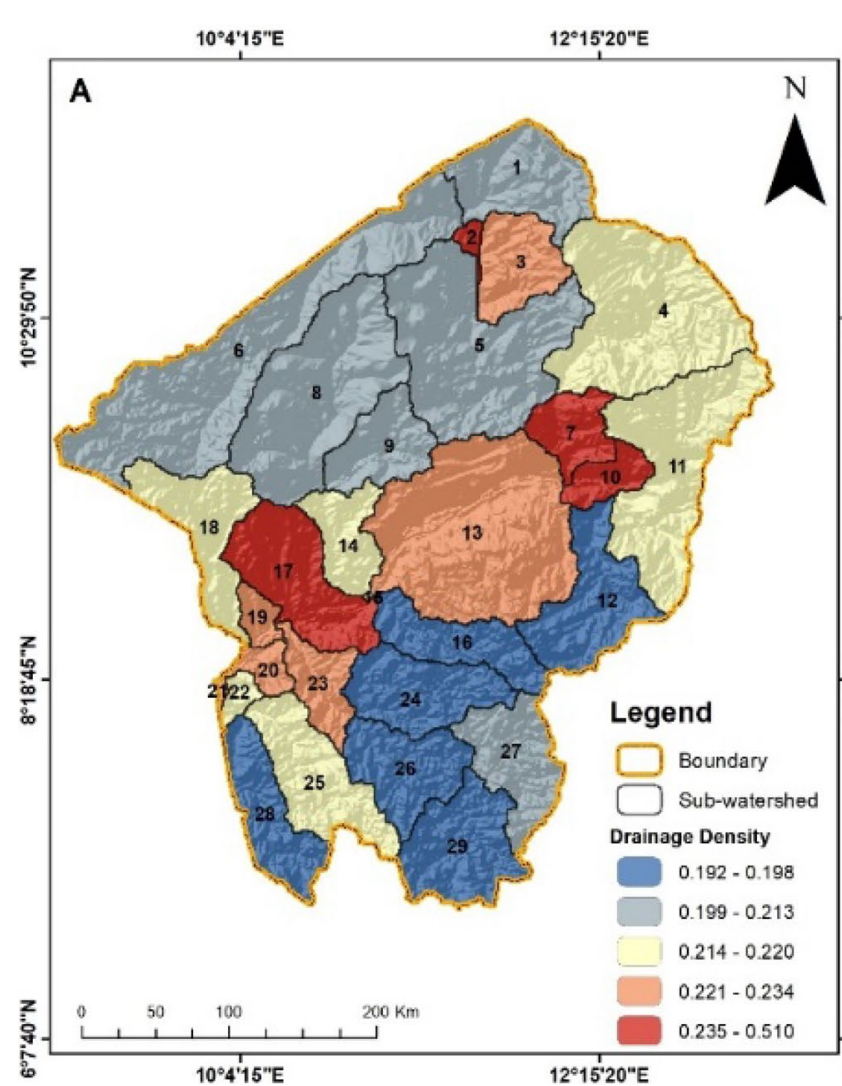

(a) drainage density

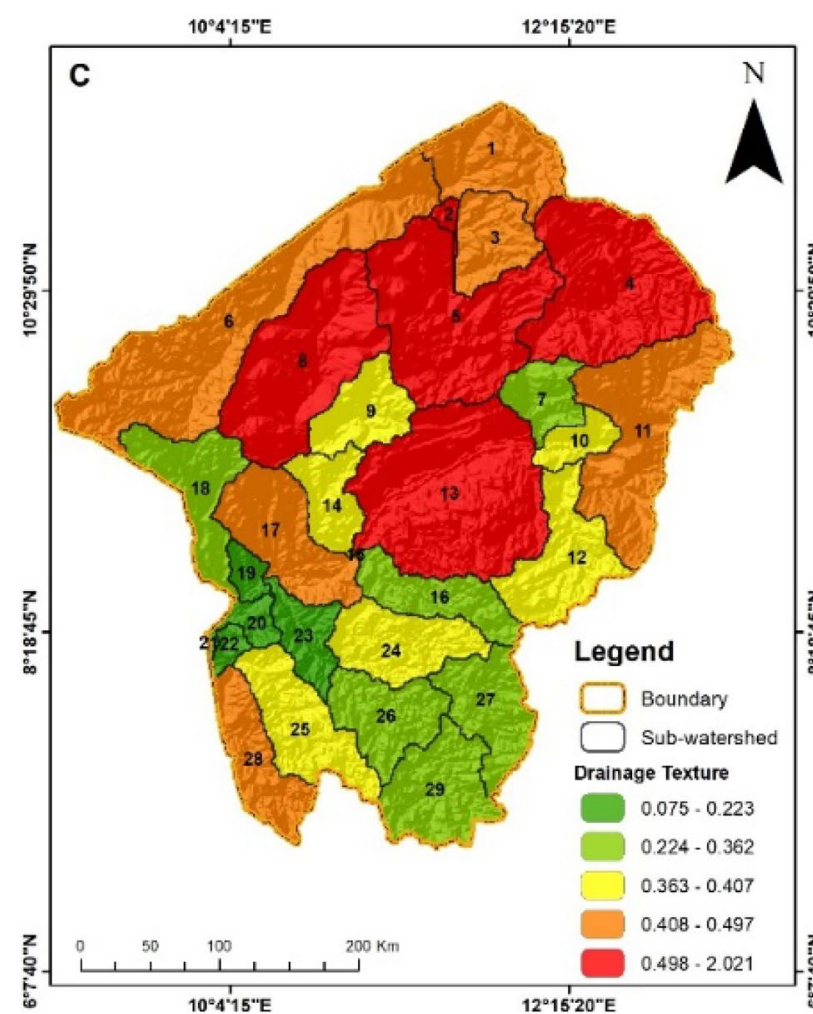

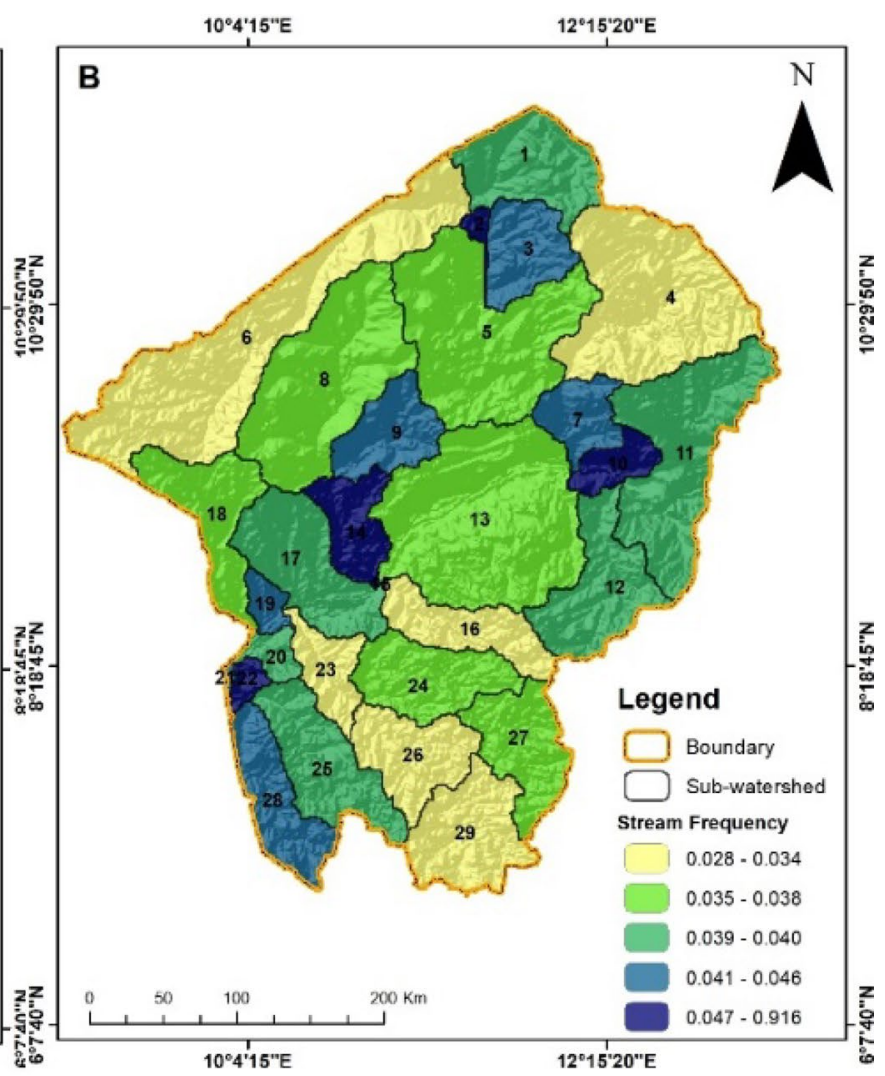

(b) stream frequency

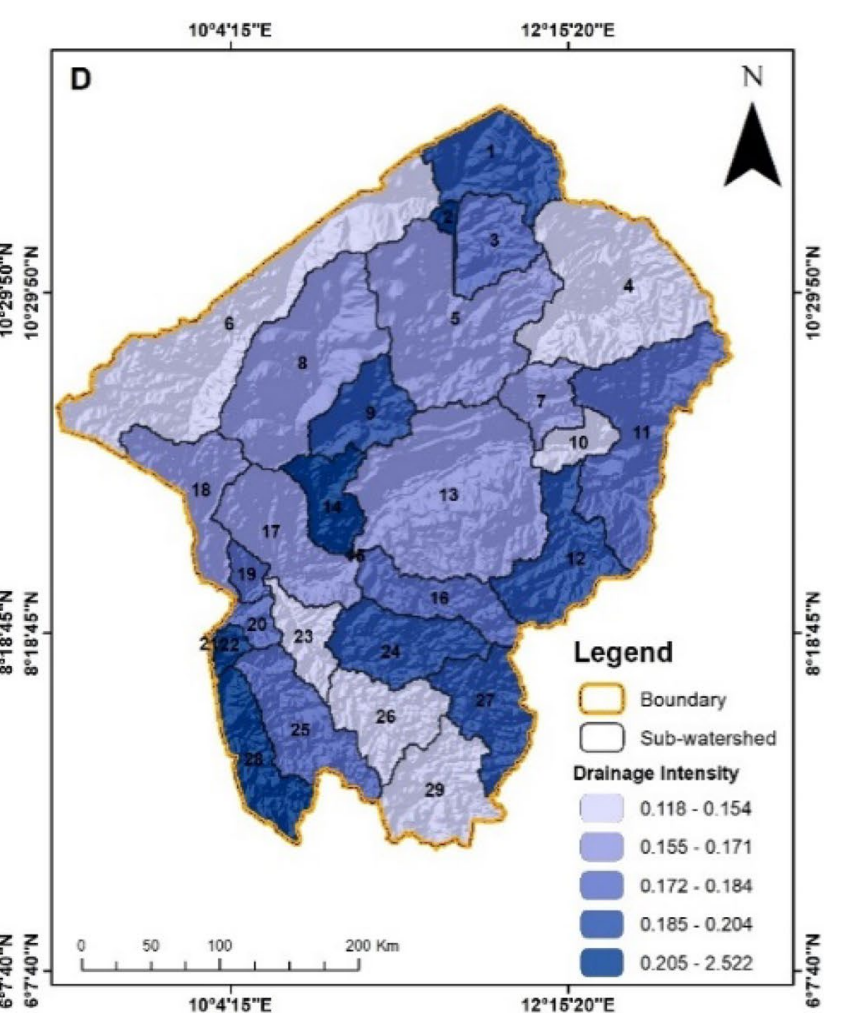

Fig. 6 a drainage density, $\mathbf{b}$ stream frequency, $\mathbf{c}$ drainage texture $\mathbf{d}$ drainage intensity $\mathbf{e}$ Infiltration number $\mathbf{f}$ Length overland flow, $\mathbf{g}$ Constant Channel Maintenance $\mathbf{h}$ Form Factor $\mathbf{i}$ Elongation ratio $\mathbf{j}$ Circulation ratio

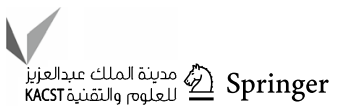



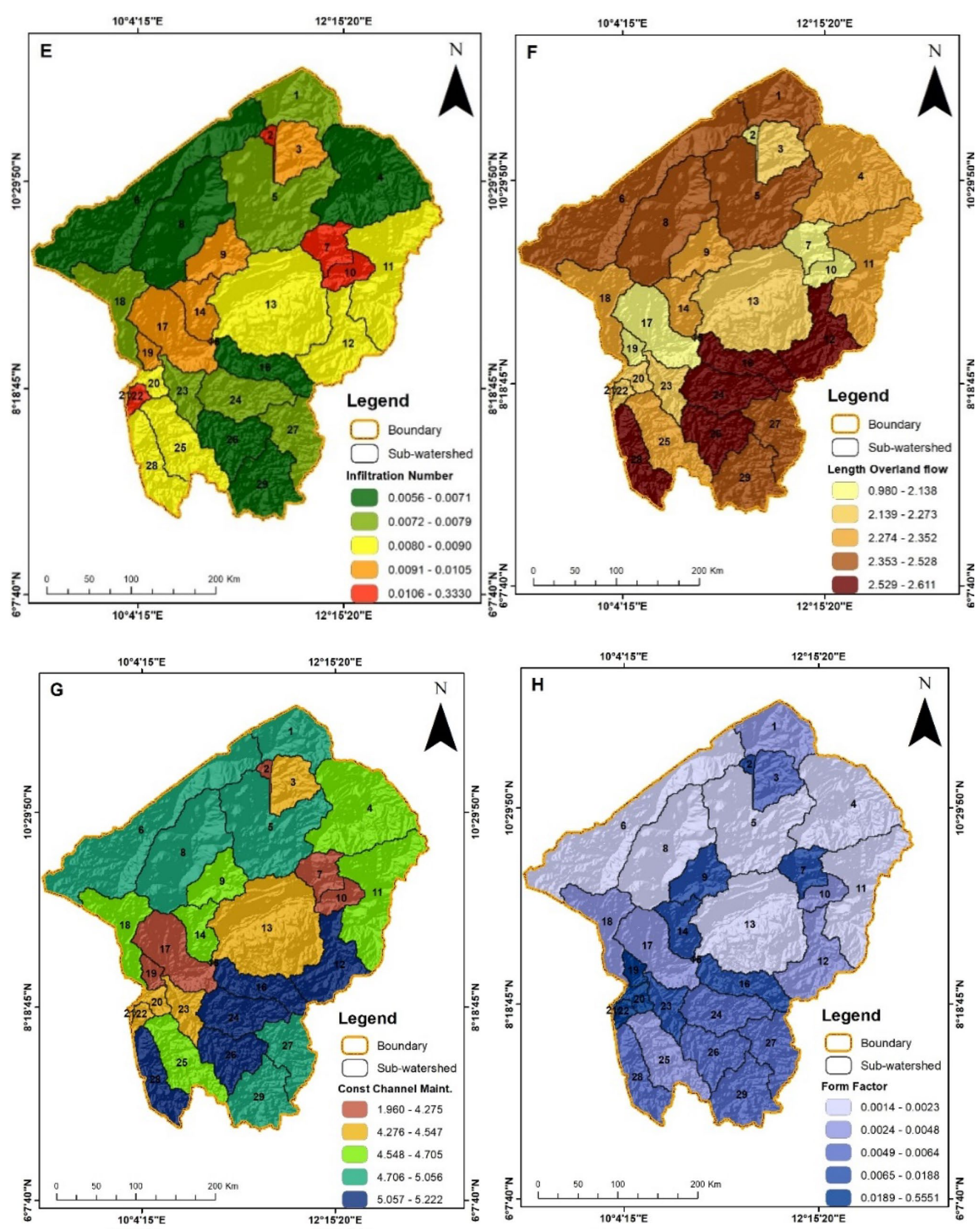

Fig. 6 (continued) 

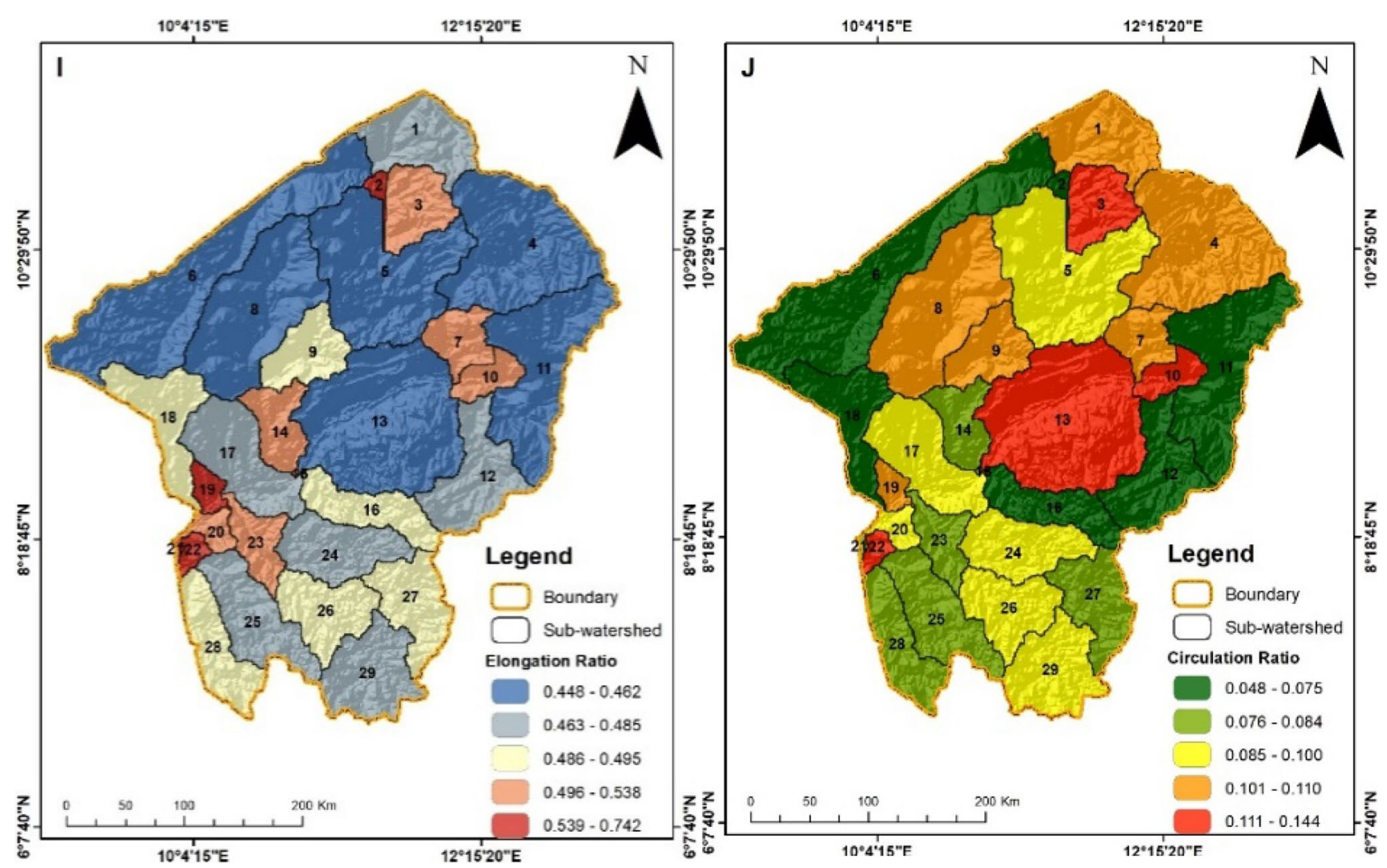

Fig. 6 (continued)

influenced by the flora, climatic condition, relief, and infiltration rate (Nag 1998). The $D d$ for the entire watershed is $0.21 \mathrm{~km} / \mathrm{km}^{2}$ which is low and that implies that the potential for surface runoff is low and infiltration capacity is high depending on precipitation intensity. A low $D d$ indicates dense vegetation, and the presence of permeable rocks with low relief (Biswas et al. 2014; Asfaw and Workineh 2019). The $D d$ of the sub-watershed ranges from 0.192 to $0.51 \mathrm{~km} /$ $\mathrm{km}^{2}$ as shown in Fig. 6a. The $D d$ is very high in sub-watersheds $2,7,10,15$, and 17 . High $D d$ is an indication that the potential for surface runoff and erosion is high. The $D d$ is very low in sub-watersheds $12,16,24,26,28$, and 29 (Table 6). Sub-watersheds with high drainage density values are vulnerable to flood hence attention should be given to drainage facilities or systems in towns and villages within the watershed so that runoff can be a channel to streams and rivers.

\section{Stream frequency $(F s)$}

This is the number of stream sections for each unit area (Horton 1945). The $F s$ of the watershed was calculated to be $0.03 / \mathrm{km}^{2}$, which is low. The $F s$ of the sub-watershed ranges from 0.028 to $0.91 / \mathrm{km}^{2}$ as shown in Fig. $6 \mathrm{~b}$. The stream frequency is very low in sub-watersheds $4,6,16,23,26$, and
29. Low Fs results in low water infiltration (Markose and Jayappa 2011) thereby reducing surface runoff and flooding is less likely in the sub-watershed (Carlston 1963). It is very high in sub-watersheds 2, 10, 14, and 22 (Table 6). High Fs in these sub-watersheds imply that they have rocky outcrops (Biswas et al. 2014) and susceptible to flood and erosion.

\section{Drainage texture (Dt)}

The $D t$ for the Watershed was calculated to be 0.42 indicating that the texture of the watershed is very coarse and this gives credence to Strahler (1957) assertion that a low $D t$ results in a rough surface while high $D t$ leads to a smooth texture. The $D t$ for 29 sub-watershed ranges from 0.075 to 2.02 as shown in Fig. 6c. The $D t$ is very high in sub-watersheds $2,4,5,8$, and 13 . It is very low in sub-watersheds 19 , 20, 21, 22, and 23(Table 6).

\section{Drainage intensity (Di)}

According to Faniran (1968), drainage intensity is the ratio of stream frequency and drainage density of the watershed. The $D i$ of the upper Benue River watershed was found to be 0.27 , which is low, and it implies that the stream frequency and drainage density have slight importance to the extent 
Table 6 Areal parameters

\begin{tabular}{|c|c|c|c|c|c|c|c|c|c|c|}
\hline Sub-watershed & $\operatorname{Re}$ & $\mathrm{Rc}$ & $\mathrm{Rf}$ & Fs & Dt & $\mathrm{Dd}$ & Di & If & $\mathrm{Lg}$ & $\mathrm{C}$ \\
\hline 1 & 0.481 & 0.107 & 0.005 & 0.038 & 0.447 & 0.206 & 0.186 & 0.008 & 2.424 & 4.849 \\
\hline 2 & 0.572 & 0.048 & 0.019 & 0.916 & 2.021 & 0.363 & 2.522 & 0.333 & 1.376 & 2.752 \\
\hline 3 & 0.495 & 0.144 & 0.006 & 0.041 & 0.455 & 0.230 & 0.180 & 0.009 & 2.178 & 4.357 \\
\hline 4 & 0.456 & 0.110 & 0.002 & 0.032 & 0.555 & 0.215 & 0.146 & 0.007 & 2.320 & 4.641 \\
\hline 5 & 0.456 & 0.087 & 0.002 & 0.036 & 0.567 & 0.212 & 0.170 & 0.008 & 2.354 & 4.708 \\
\hline 6 & 0.448 & 0.049 & 0.002 & 0.030 & 0.408 & 0.201 & 0.151 & 0.006 & 2.494 & 4.987 \\
\hline 7 & 0.506 & 0.101 & 0.007 & 0.043 & 0.335 & 0.250 & 0.171 & 0.011 & 2.003 & 4.007 \\
\hline 8 & 0.459 & 0.109 & 0.002 & 0.034 & 0.575 & 0.208 & 0.165 & 0.007 & 2.405 & 4.809 \\
\hline 9 & 0.495 & 0.104 & 0.007 & 0.043 & 0.407 & 0.213 & 0.204 & 0.009 & 2.352 & 4.705 \\
\hline 10 & 0.521 & 0.113 & 0.003 & 0.056 & 0.373 & 0.471 & 0.118 & 0.026 & 1.061 & 2.122 \\
\hline 11 & 0.462 & 0.068 & 0.002 & 0.040 & 0.497 & 0.216 & 0.184 & 0.009 & 2.316 & 4.632 \\
\hline 12 & 0.480 & 0.073 & 0.005 & 0.040 & 0.396 & 0.197 & 0.204 & 0.008 & 2.534 & 5.068 \\
\hline 13 & 0.449 & 0.114 & 0.001 & 0.035 & 0.710 & 0.225 & 0.156 & 0.008 & 2.222 & 4.444 \\
\hline 14 & 0.502 & 0.083 & 0.008 & 0.048 & 0.363 & 0.216 & 0.222 & 0.010 & 2.313 & 4.626 \\
\hline 15 & 0.742 & 0.125 & 0.555 & 0.289 & 0.135 & 0.510 & 0.567 & 0.148 & 0.980 & 1.960 \\
\hline 16 & 0.492 & 0.075 & 0.007 & 0.034 & 0.282 & 0.192 & 0.176 & 0.006 & 2.611 & 5.222 \\
\hline 17 & 0.478 & 0.098 & 0.003 & 0.039 & 0.456 & 0.244 & 0.158 & 0.009 & 2.047 & 4.095 \\
\hline 18 & 0.485 & 0.062 & 0.005 & 0.036 & 0.302 & 0.213 & 0.168 & 0.008 & 2.350 & 4.700 \\
\hline 19 & 0.542 & 0.102 & 0.020 & 0.042 & 0.203 & 0.234 & 0.181 & 0.010 & 2.138 & 4.275 \\
\hline 20 & 0.538 & 0.099 & 0.020 & 0.039 & 0.195 & 0.225 & 0.174 & 0.009 & 2.222 & 4.445 \\
\hline 21 & 0.617 & 0.083 & 0.143 & 0.046 & 0.075 & 0.231 & 0.198 & 0.010 & 2.169 & 4.338 \\
\hline 22 & 0.554 & 0.119 & 0.032 & 0.050 & 0.218 & 0.220 & 0.227 & 0.011 & 2.273 & 4.547 \\
\hline 23 & 0.507 & 0.075 & 0.008 & 0.033 & 0.223 & 0.223 & 0.150 & 0.007 & 2.239 & 4.477 \\
\hline 24 & 0.485 & 0.100 & 0.006 & 0.038 & 0.406 & 0.194 & 0.194 & 0.007 & 2.571 & 5.143 \\
\hline 25 & 0.481 & 0.081 & 0.004 & 0.039 & 0.402 & 0.214 & 0.184 & 0.008 & 2.341 & 4.682 \\
\hline 26 & 0.491 & 0.100 & 0.006 & 0.030 & 0.308 & 0.194 & 0.154 & 0.006 & 2.583 & 5.165 \\
\hline 27 & 0.491 & 0.083 & 0.005 & 0.038 & 0.362 & 0.206 & 0.186 & 0.008 & 2.430 & 4.859 \\
\hline 28 & 0.489 & 0.084 & 0.006 & 0.046 & 0.420 & 0.197 & 0.232 & 0.009 & 2.537 & 5.075 \\
\hline 29 & 0.481 & 0.098 & 0.005 & 0.028 & 0.320 & 0.198 & 0.143 & 0.006 & 2.528 & 5.056 \\
\hline
\end{tabular}

to which agents of denudation have lowered the land surface. The $D i$ varies from 0.118 to 2.52 with low $D i$ values in sub-watersheds $4,6,10,13,17,23,26$, and 29. The high $D i$ values are in sub-watersheds 2, 14, and 28 as shown in Fig. 6d and Table 6.

\section{Infiltration number (If)}

It is a function of drainage density and stream frequency. According to Prabhakaran and Raj (2018) the If reflects the water transmission potential of a watershed. The If ranges from 0.0056 to 0.33 in the watershed as shown in Fig. 6e. The entire watershed has an If of 0.024 , which is low. Faniran (1968) noted that areas with lower If values are an indication of higher infiltration and lower surface runoff. Sub-watershed with low If values includes: 4, 6, 8, 16, 26, and 29 indicating that amount of water entering into the soil is high and by implication runoff is low, but it depends if the precipitation rate does not exceed infiltration rate. However, sub-watersheds $2,7,10,15$, and 22 have high If values which mean the water infiltration low and surface runoff is high (Table 6).

\section{Length of overland flow $(L g)$}

This refers to the length at which rainfall runs over the surface before it drains into a stream channel (Horton 1945). The $L g$ for the upper Benue River watershed was calculated to be $2.4 \mathrm{~km}$, which implies that the watershed has a long flow path with reduced runoff. The $L g$ ranges from 0.98 to 2.61 in the 29 sub-watersheds (Fig. 5f). The values of the $L g$ are small in sub-watersheds $2,7,10,15$, 17 , and 19 which means that surface runoff will enter stream channels very rapidly signifying that these areas are characterized by steep slopes that lead to high runoff (Thomas et al. 2010). The areas with low $L g$ values 
are highly vulnerable to flooding due to reduced water percolation into the soil (Olszevski et al. 2011). Areas with high $L g$ values have high infiltration and less direct surface runoff especially in sub-watersheds $12,16,24$, 26 , and 28 (Table 6).

\section{Constant of channel maintenance $(C)$}

The $C$ of the upper Benue watershed was calculated as $4.44 \mathrm{~km} / \mathrm{km}^{2}$, which signifies that it is least erodible (Schumm 1956). Across the entire watershed, the $C$ varies from 1.96 to 5.22 (Fig. 6g and Table 6). Sub-watersheds $2,7,10,15,17$, and 19 have very low $C$ values indicating that they are highly erodible with low vegetal cover and low infiltration (Mahala 2019). Higher $C$ values are in sub-watersheds $12,16,24,26$, and 28 signifying that they are least erodible which also reflects that they have dense vegetation and high infiltration.

\section{Form factor $(R f)$}

The $R f$ is the mathematical index normally used to characterize diverse watershed shapes (Horton 1932). The value of the $R f$ ranges from 0.1 to 0.8 . The smaller the value of $R f$, the more elongated will be the watershed. The $R f$ for the watershed is 0.02, which means that the upper Benue River watershed is elongated and has a low peak flow of longer duration. Figure $6 \mathrm{~h}$ and Table 6 show that sub-watersheds $2,7,9,14,19,20,21$, and 22 have high values which means they have high peak flows of shorter duration (Singh and Singh 1997).

\section{Elongation ratio $(R e)$}

The $R e$ is categorized into four; $<0.7$ (elongated), $0.7-0.8$ (less elongated), 0.8-0.9(oval) and $>0.9$ (circular) (Strahler 1964a, b). Thus, the higher the value of $R e$, the more circular shape of the watershed and vice-versa. According to Strahler $(1964 a, b)$, when the value is close to 1.0 , it typifies an area with very low relief, while that of 0.6 to 0.8 is typically linked with high relief. The upper Benue River watershed has a $R e$ of 0.5 , which means that the watershed is elongated. Across the 29 sub-watersheds, the $R e$ varies from 0.44 to 0.74 (Fig. 6i). It is less elongated in sub-watersheds 2, 19, 21 , and 22 indicating moderate relief (Table 6.)

\section{Circulatory ratio $(\mathrm{Rc})$}

The value of the $R c$ varies from 0 (inline) to 1 (in a circle). The $R c$ is generally low across all the sub-watershed, and it varies from 0.048 to 0.144 (Fig. 6j and Table 6). The $R c$ value for the entire watershed is 0.10 which implies that the watershed is more or less elongated and is characterized by medium to low relief (Strahler 1964a, b). The low $R c$ values are as a result of the structure of the rocks that control the drainage (Miller 1953). Venkatesh and Anshumali (2019) in their study observed an $R c$ of 0.13 and asserted that the low Rc was a result of rocks that are highly permeable and homogenous.

\section{Relationship between different shape parameter}

In a watershed, there is a mutual relationship between these parameters (elongation ratio, circulatory ratio, and form factor). It was observed that there was a decrease in value in the elongation ratio, circulatory ratio, and form factor. However, in sub-watersheds 15 and 21, the form factor is higher than the circulatory ratio (Table 6). This is attributed to the structural control and lithology of the area (Fig. 7). This anomaly was observed by Altaf et al.,(2013) and Biswas et al. (2014) in their studies.

\section{Relief parameter}

\section{Watershed perimeter and length}

The watershed perimeter is the exterior boundary of the watershed that surrounds its area (Schumm 1956). The watershed perimeter was calculated using the ArcGIS minimum bounding geometry tool and the perimeter was $12,411.9 \mathrm{~km}$ while the length of the watershed was calculated to be $4306.12 \mathrm{~km}$.
Fig. 7 The relation between different shape parameters shows decrease values

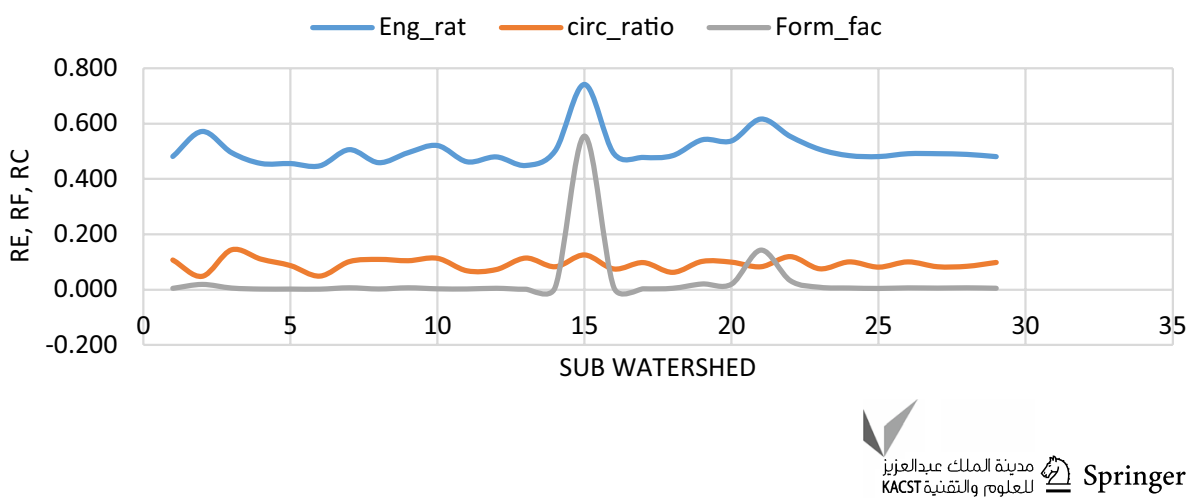



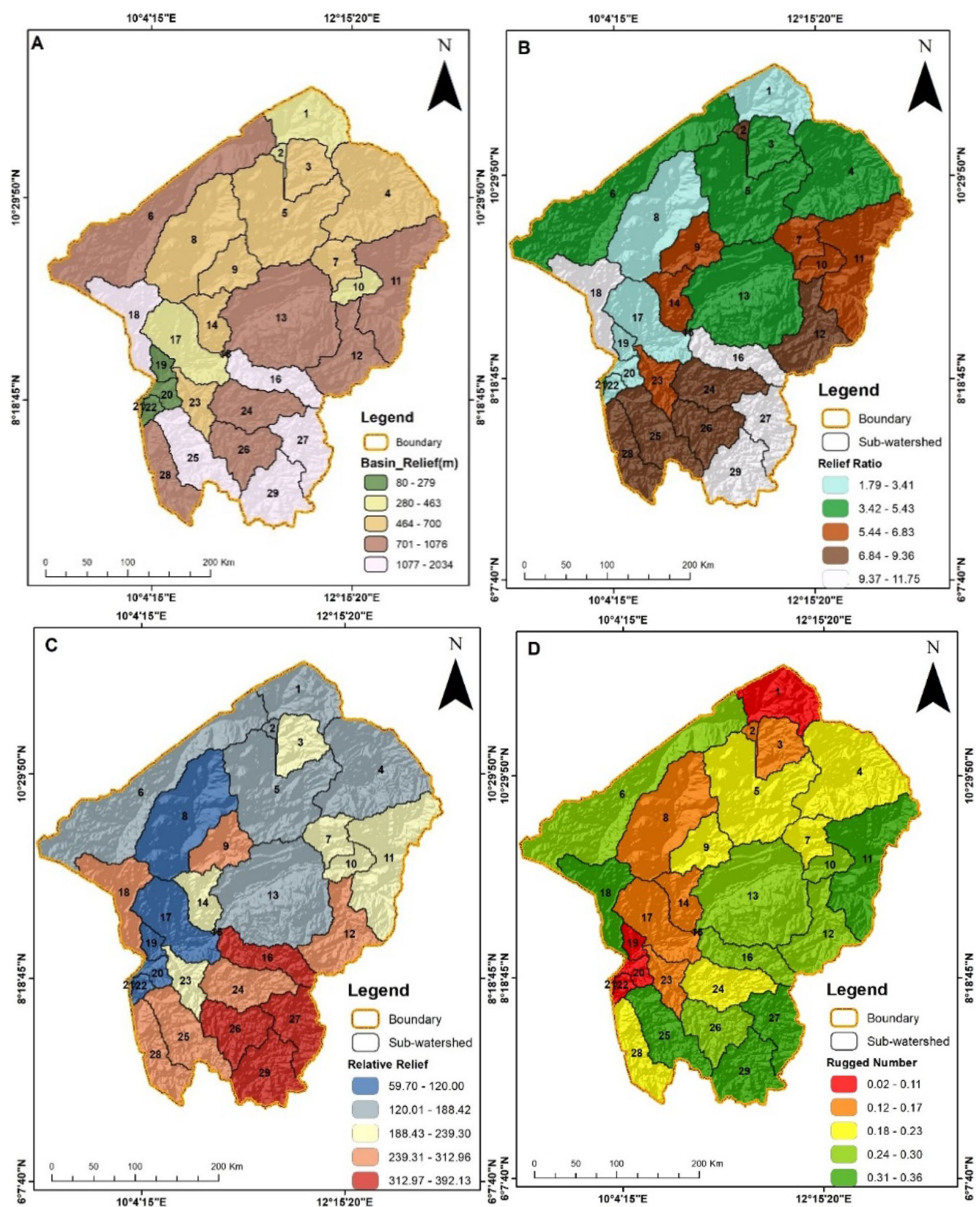

Fig. 8 a Watershed Relief b Relief Ratio c Relative Relief $\mathbf{d}$ Rugged Number e Compact Coefficient $\mathbf{f}$ Shape Factor $\mathbf{g}$ Lemniscate h Gradient Ratio 

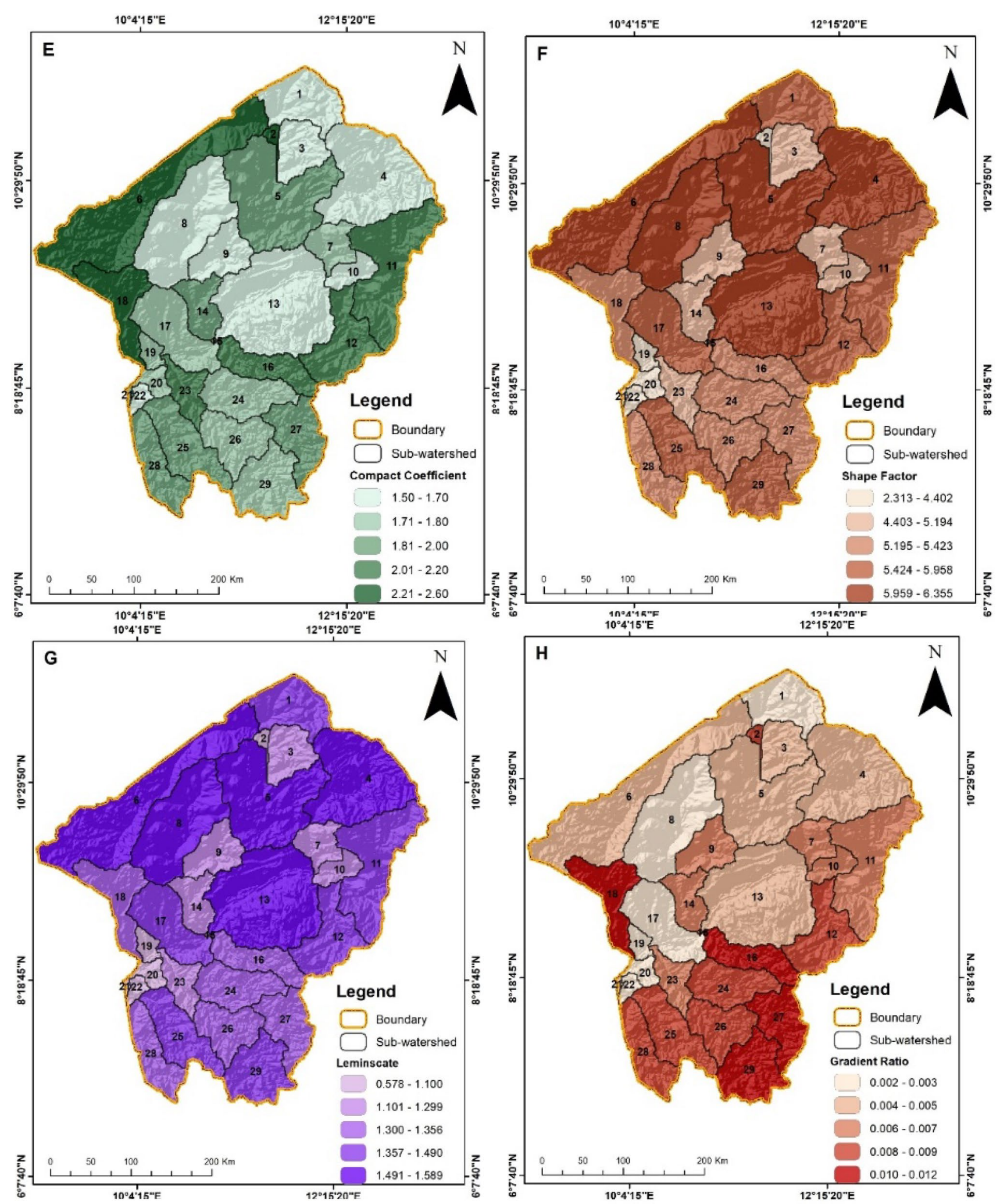

Fig. 8 (continued) 
Table 7 Relief Parameter

\begin{tabular}{|c|c|c|c|c|c|c|c|c|}
\hline Sub-watershed & $\mathrm{Rr}$ & Rhp & $\mathrm{R}$ & $\mathrm{Rn}$ & $\mathrm{Rf}$ & $\mathrm{K}$ & Gr & $\mathrm{Cc}$ \\
\hline 1 & 3.17 & 121.53 & 530 & 0.1093 & 5.4947 & 1.3737 & 0.0032 & 1.7 \\
\hline 2 & 7.69 & 166.57 & 305 & 0.1108 & 3.8922 & 0.9730 & 0.0077 & 2.6 \\
\hline 3 & 5.43 & 234.88 & 718 & 0.1648 & 5.1934 & 1.2984 & 0.0054 & 1.5 \\
\hline 4 & 3.66 & 150.38 & 960 & 0.2069 & 6.1183 & 1.5296 & 0.0037 & 1.7 \\
\hline 5 & 3.57 & 130.09 & 940 & 0.1997 & 6.1276 & 1.5319 & 0.0036 & 1.9 \\
\hline 6 & 4.77 & 132.98 & 1465 & 0.2937 & 6.3551 & 1.5888 & 0.0048 & 2.6 \\
\hline 7 & 6.75 & 239.30 & 743 & 0.1854 & 4.9718 & 1.2429 & 0.0067 & 1.8 \\
\hline 8 & 2.82 & 114.48 & 701 & 0.1458 & 6.0431 & 1.5108 & 0.0028 & 1.7 \\
\hline 9 & 6.73 & 247.94 & 890 & 0.1892 & 5.1944 & 1.2986 & 0.0067 & 1.7 \\
\hline 10 & 6.17 & 224.95 & 531 & 0.2502 & 4.6922 & 1.1731 & 0.0062 & 1.6 \\
\hline 11 & 6.29 & 200.45 & 1476 & 0.3187 & 5.9581 & 1.4895 & 0.0063 & 2.2 \\
\hline 12 & 8.18 & 259.25 & 1406 & 0.2774 & 5.5300 & 1.3825 & 0.0082 & 2.1 \\
\hline 13 & 4.44 & 188.42 & 1334 & 0.3002 & 6.3215 & 1.5804 & 0.0044 & 1.6 \\
\hline 14 & 6.83 & 220.97 & 809 & 0.1749 & 5.0576 & 1.2644 & 0.0068 & 2 \\
\hline 15 & 11.75 & 316.34 & 47 & 0.0240 & 2.3130 & 0.5782 & 0.0118 & 1.5 \\
\hline 16 & 11.24 & 352.31 & 1576 & 0.3018 & 5.2683 & 1.3171 & 0.0112 & 2.1 \\
\hline 17 & 2.56 & 94.63 & 457 & 0.1116 & 5.5739 & 1.3935 & 0.0026 & 1.8 \\
\hline 18 & 10.25 & 298.12 & 1618 & 0.3443 & 5.4216 & 1.3554 & 0.0102 & 2.3 \\
\hline 19 & 1.79 & 59.70 & 112 & 0.0262 & 4.3387 & 1.0847 & 0.0018 & 1.8 \\
\hline 20 & 1.87 & 61.86 & 124 & 0.0279 & 4.4016 & 1.1004 & 0.0019 & 1.8 \\
\hline 21 & 3.86 & 101.46 & 81 & 0.0187 & 3.3472 & 0.8368 & 0.0039 & 2 \\
\hline 22 & 3.41 & 120.00 & 176 & 0.0387 & 4.1507 & 1.0377 & 0.0034 & 1.6 \\
\hline 23 & 6.44 & 196.60 & 697 & 0.1557 & 4.9523 & 1.2381 & 0.0064 & 2.1 \\
\hline 24 & 7.37 & 271.61 & 1164 & 0.2263 & 5.4233 & 1.3558 & 0.0074 & 1.8 \\
\hline 25 & 9.36 & 312.96 & 1579 & 0.3373 & 5.5010 & 1.3753 & 0.0094 & 2 \\
\hline 26 & 8.74 & 317.85 & 1309 & 0.2534 & 5.2714 & 1.3178 & 0.0087 & 1.8 \\
\hline 27 & 11.75 & 388.12 & 1771 & 0.3645 & 5.2712 & 1.3178 & 0.0118 & 2 \\
\hline 28 & 7.77 & 260.44 & 1135 & 0.2237 & 5.3255 & 1.3314 & 0.0078 & 1.9 \\
\hline 29 & 10.66 & 392.13 & 1803 & 0.3566 & 5.5071 & 1.3768 & 0.0107 & 1.8 \\
\hline
\end{tabular}

\section{Basin relief $(R)$}

The $R$ indicates differences in height. The $R$ ranges from 80 to $2034 \mathrm{~m}$ (Fig. 8a). Sub-watersheds 16, 18, 25, 27, and 29 show high relief. The $R$ is, however, low in sub-watersheds $2,19,20,21$, and 22 (Table 8). $R$ influences potential energy (Strahler 1964a, b) and loads of deposits that can be conveyed and discharged (Hadley and Schumm 1961). Parts of the sub-watershed with high $R$ will most likely have a high rate of deposit and discharge.

\section{Relief ratio $(R r)$}

The $R r$ is the total relief of a watershed, i.e. an elevation difference of the lowest and highest point of the watershed (Schumm 1956). It measures the overall steepness of the drainage watershed and the force of the erosion process in the watershed (Strahler 1964a, b). The $R r$ of the upper Benue
River watershed is 0.0062 which is low signifying that the force of the erosion process is low. The low $R r$ is attributed to the presence of resistance rocks (Kaliraj et al. 2015). The $R r$ in the 29 sub-watershed varies from 0.002 to 0.012 (Fig. 8b). The values of the $R r$ are high in sub-watersheds $16,18,27$, and 29 indicating steep slope and presence of resistant rock. Sub-watershed with low $R r$ values include; $1,8,17,19,20$, and 22 (Table 7).

\section{Relative relief $(R h p)$}

It reflects the variance in height in the area (Chai 2014). The Rhp of upper Benue River watershed was estimated to be 212.9. It varies from 59.70 to 392.12 (Fig. 8c). Subwatershed with high $R h p$ values includes: $16,26,27$, and 29. Low $R h p$ value includes: sub-watershed 3, 7, 10, 11, 14 and 23 (Table 7). 
Fig.9 a Hypsometric integral of upper Benue River watershed b Hypsometric curve

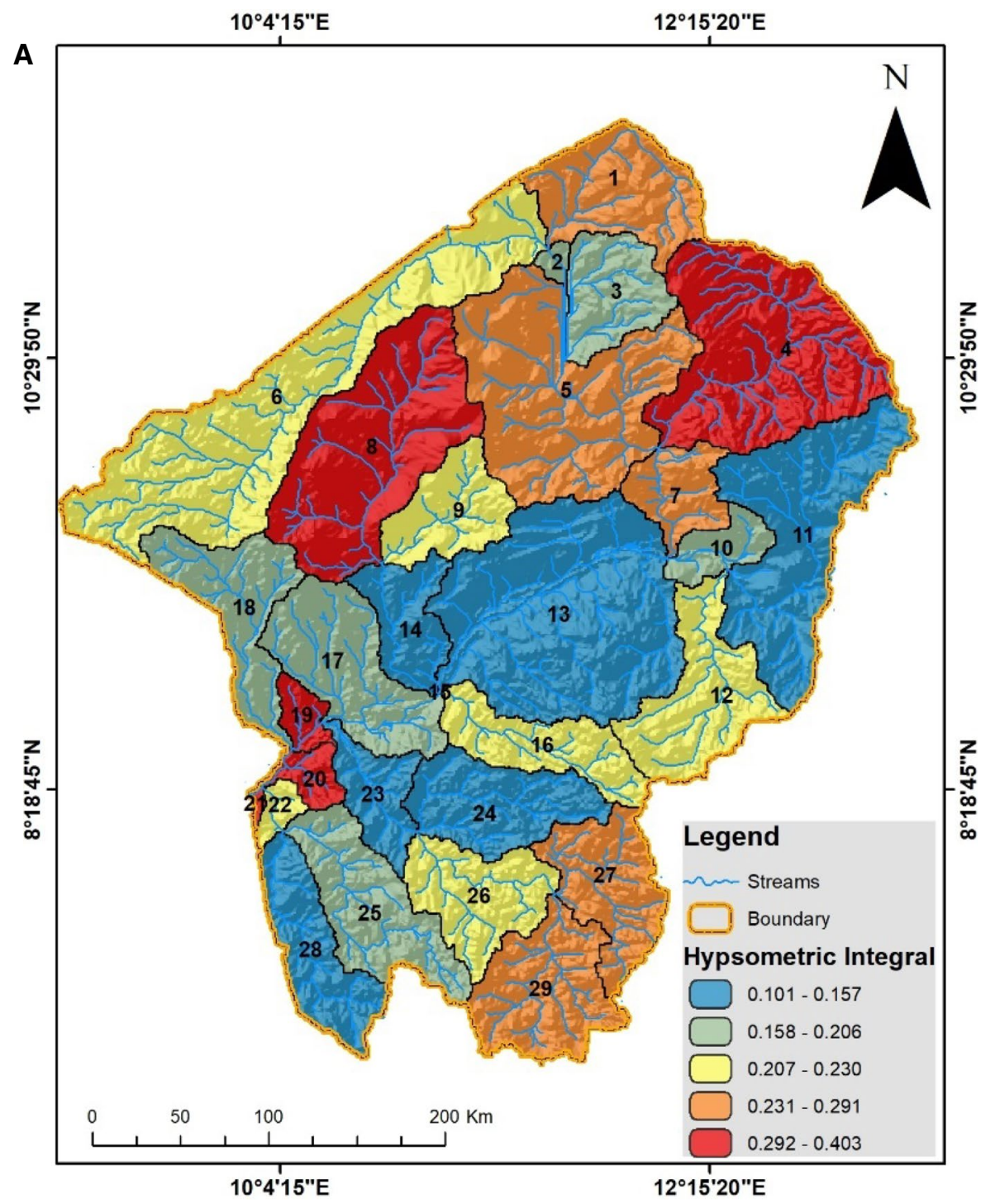

B

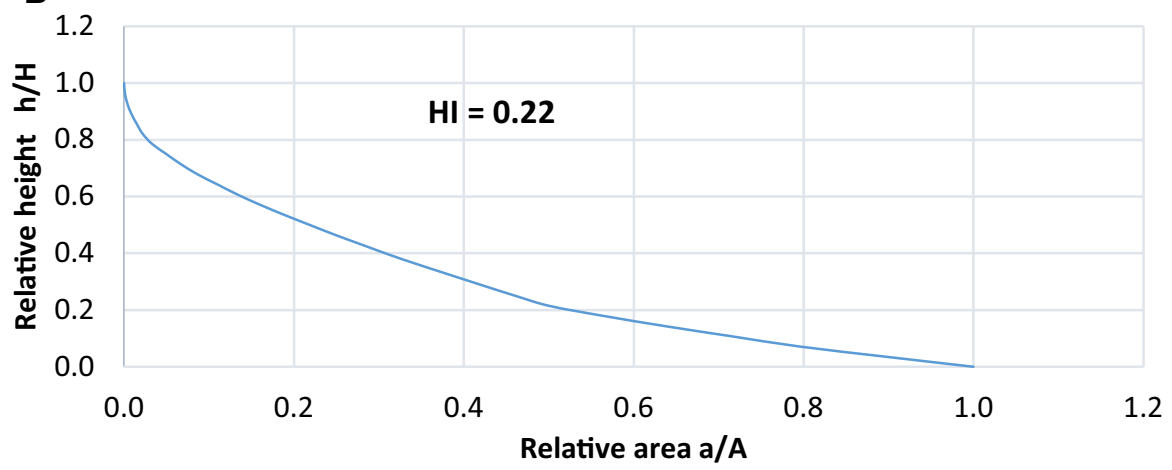

\section{Ruggedness number (Rn)}

The $R n$ values range from 0.019 to 0.364 (Fig. $8 \mathrm{~d}$ ). Generally, the $R n$ of the watershed is 0.2 which is low and it connotes that the watershed is matured with a gentle slope (Venkatesh and Anshumali 2019). The higher Rn number value was observed in sub-watersheds $11,18,25,27$, and 29 . Areas, where the values of the $R n$ are low, can be seen in sub-watersheds 1, 19, 20, 21, and 22 (Table 7). High $R n$ shows that the region is predisposed to erosion due to the structural complexity of the terrain (Samal et al. 2015) and slopes are steep and long (Chow 1964). 
Table 8 Hypsometric Integral (HI)

\begin{tabular}{|c|c|c|c|c|c|c|}
\hline $\begin{array}{l}\text { Sub-Water- } \\
\text { shed (SW) }\end{array}$ & Min elevation & Max elevation & Mean elevation & Area & $\mathrm{HI}$ & Stage \\
\hline 1 & 257 & 687 & 393.35 & 5090.25 & 0.270 & Old \\
\hline 2 & 241 & 470 & 285.37 & 403.72 & 0.162 & Old \\
\hline 3 & 240 & 823 & 376.54 & 3363.15 & 0.204 & Old \\
\hline 4 & 182 & 1054 & 484.71 & $11,219.42$ & 0.319 & Mature \\
\hline 5 & 182 & 891 & 396.84 & $11,343.11$ & 0.233 & Old \\
\hline 6 & 258 & 1612 & 580.61 & $14,825.69$ & 0.227 & Old \\
\hline 7 & 143 & 859 & 316.72 & 2439.06 & 0.252 & Old \\
\hline 8 & 189 & 857 & 413.95 & $10,240.81$ & 0.329 & Mature \\
\hline 9 & 193 & 879 & 384.50 & 3366.05 & 0.226 & Old \\
\hline 10 & 141 & 558 & 222.43 & 1576.22 & 0.173 & Old \\
\hline 11 & 150 & 1455 & 376.17 & 9229.47 & 0.157 & Old \\
\hline 12 & 152 & 1486 & 439.14 & 5336.07 & 0.208 & Old \\
\hline 13 & 113 & 1362 & 304.08 & $14,303.60$ & 0.149 & Old \\
\hline 14 & 114 & 768 & 204.89 & 2771.77 & 0.122 & Old \\
\hline 15 & 114 & 144 & 119.75 & 6.92 & 0.281 & Old \\
\hline 16 & 114 & 1571 & 447.57 & 3733.15 & 0.220 & Old \\
\hline 17 & 102 & 530 & 185.03 & 5697.10 & 0.206 & Old \\
\hline 18 & 103 & 1514 & 425.83 & 4598.72 & 0.204 & Old \\
\hline 19 & 97 & 194 & 129.06 & 897.46 & 0.351 & Mature \\
\hline 20 & 94 & 206 & 128.05 & 996.56 & 0.317 & Mature \\
\hline 21 & 90 & 154 & 113.56 & 131.75 & 0.403 & Mature \\
\hline 22 & 96 & 174 & 123.34 & 641.48 & 0.218 & Old \\
\hline 23 & 102 & 576 & 166.12 & 2363.98 & 0.125 & Old \\
\hline 24 & 142 & 1170 & 308.52 & 4604.26 & 0.155 & Old \\
\hline 25 & 102 & 1604 & 367.40 & 5173.54 & 0.171 & Old \\
\hline 26 & 143 & 1300 & 414.39 & 4251.28 & 0.230 & Old \\
\hline 27 & 249 & 1900 & 638.60 & 4308.39 & 0.231 & Old \\
\hline 28 & 101 & 1088 & 209.71 & 4002.66 & 0.101 & Old \\
\hline 29 & 249 & 1964 & 748.20 & 5192.36 & 0.291 & Old \\
\hline
\end{tabular}

\section{Compactness coefficient (Cc)}

The $\mathrm{Cc}$ of the entire watershed was calculated to be 1.9, which is low, and it indicates high infiltration and low erosion risk. The $\mathrm{Cc}$ of the watershed ranges from 1.50 to 2.60 (Fig. 8e). Sub-watersheds 2, 6, and 18 have high Cc values. The low Cc values were observed in sub-watersheds $1,3,4$, $8,10,13$, and 22(Table 7).

\section{Shape factor (Rf)}

The $R f$ gives insight into the circular behaviour of a watershed (Altaf et al., 2013). The rapid response of a watershed is greater after rainfall and that depends on how great the circular character of the watershed is (Tucker and Bras 1998). The $R f$ of the upper Benue watershed was found to be 5.13. The lowest $R f$ values were observed in sub-watersheds 2 , $15,19,20,21$, and 22 indicating the long lag time and high flood risk. The value of the $R f$ is high in sub-watersheds 4 ,
5, 6, 8, and 13 which means that the lag time is short (Fig. $8 \mathrm{f}$ and Table 7).

\section{Lemniscate (k)}

The $K$ is used to determine the slope of the watershed (Chorley et al. 1957). The $k$ value of the watershed was found to be 1.28. $K$ value across the 29 sub-watersheds ranged from 0.58 to 1.59 with sub-watersheds $4,5,6,8$, and 13 having high $k$ value. Sub-watersheds $2,19,20,21$, and 22 have a low $k$ value (Fig. $8 \mathrm{~g}$ and Table 7). The higher the $\mathrm{K}$ value, the higher the susceptibility of the area to soil erosion.

\section{Gradient ratio $(\mathrm{Gr})$}

The $G r$ is a vital indicator of runoff assessment and slope channel (Rai et al. 2020). The $G r$ value ranges from 0.0017 to 0.0117 and the entire watershed has a $G r$ value of 0.0063 
Table 9 Sub-watershed compound factor and priority

\begin{tabular}{|c|c|c|c|c|c|c|c|c|c|c|c|c|c|c|c|}
\hline Sub-watershed & Rbm & Dd & Fs & Dt & $\operatorname{Re}$ & $\mathrm{Rc}$ & $\mathrm{Rf}$ & $\mathrm{Cc}$ & $\mathrm{C}$ & $\mathrm{Rr}$ & $\mathrm{Rn}$ & $\mathrm{Rf}$ & $\mathrm{Lg}$ & $\begin{array}{l}\text { Com- } \\
\text { pound } \\
\text { factor }\end{array}$ & Priority \\
\hline 1 & 11 & 21 & 8 & 9 & 19 & 4 & 17 & 21 & 9 & 25 & 24 & 11 & 9 & 10.0 & Low \\
\hline 2 & 26 & 3 & 1 & 1 & 2 & 29 & 3 & 1 & 27 & 10 & 23 & 27 & 27 & 9.4 & Moderate \\
\hline 3 & 12 & 8 & 9 & 8 & 10 & 1 & 12 & 28 & 22 & 18 & 19 & 18 & 22 & 9.8 & Moderate \\
\hline 4 & 1 & 15 & 23 & 7 & 24 & 5 & 24 & 22 & 15 & 22 & 14 & 4 & 15 & 10.0 & Low \\
\hline 5 & 4 & 19 & 10 & 4 & 25 & 17 & 25 & 12 & 11 & 23 & 15 & 3 & 11 & 10.1 & Low \\
\hline 6 & 7 & 23 & 24 & 11 & 28 & 28 & 26 & 2 & 7 & 19 & 8 & 1 & 7 & 9.2 & Moderate \\
\hline 7 & 22 & 4 & 11 & 20 & 8 & 9 & 9 & 14 & 26 & 13 & 17 & 21 & 26 & 9.0 & High \\
\hline 8 & 8 & 20 & 25 & 3 & 26 & 6 & 26 & 23 & 10 & 26 & 21 & 5 & 10 & 11.0 & Very low \\
\hline 9 & 17 & 17 & 12 & 13 & 11 & 10 & 10 & 24 & 12 & 14 & 16 & 19 & 12 & 8.9 & High \\
\hline 10 & 23 & 2 & 3 & 17 & 7 & 7 & 21 & 25 & 28 & 17 & 11 & 23 & 28 & 10.7 & Low \\
\hline 11 & 2 & 13 & 13 & 6 & 27 & 25 & 28 & 4 & 16 & 16 & 5 & 6 & 16 & 9.8 & Moderate \\
\hline 12 & 13 & 25 & 14 & 15 & 20 & 26 & 16 & 5 & 5 & 8 & 9 & 8 & 5 & 7.5 & very high \\
\hline 13 & 14 & 9 & 15 & 2 & 29 & 8 & 29 & 26 & 20 & 20 & 7 & 2 & 20 & 10.8 & Very low \\
\hline 14 & 15 & 14 & 4 & 18 & 12 & 18 & 7 & 8 & 17 & 12 & 18 & 20 & 17 & 8.6 & High \\
\hline 15 & 29 & 1 & 2 & 28 & 1 & 2 & 1 & 29 & 29 & 1 & 28 & 29 & 29 & 9.2 & Very low \\
\hline 16 & 19 & 29 & 26 & 24 & 13 & 19 & 11 & 6 & 1 & 3 & 6 & 15 & 1 & 5.7 & very high \\
\hline 17 & 16 & 5 & 16 & 7 & 21 & 11 & 23 & 15 & 25 & 27 & 22 & 7 & 25 & 11.6 & Very low \\
\hline 18 & 5 & 18 & 17 & 23 & 14 & 27 & 18 & 3 & 13 & 5 & 3 & 12 & 13 & 7.3 & very high \\
\hline 19 & 24 & 6 & 18 & 25 & 5 & 12 & 5 & 16 & 24 & 28 & 27 & 25 & 24 & 10.9 & Very low \\
\hline 20 & 25 & 10 & 19 & 26 & 6 & 13 & 6 & 17 & 21 & 29 & 26 & 24 & 21 & 10.9 & Very low \\
\hline 21 & 28 & 7 & 5 & 29 & 3 & 20 & 2 & 9 & 23 & 21 & 29 & 28 & 23 & 10.4 & Low \\
\hline 22 & 27 & 12 & 6 & 27 & 4 & 3 & 4 & 27 & 18 & 24 & 25 & 26 & 18 & 10.1 & Low \\
\hline 23 & 6 & 11 & 27 & 12 & 9 & 21 & 8 & 7 & 19 & 15 & 20 & 22 & 19 & 9.3 & Moderate \\
\hline 24 & 10 & 26 & 20 & 14 & 15 & 14 & 13 & 18 & 3 & 11 & 12 & 13 & 3 & 7.6 & very high \\
\hline 25 & 9 & 16 & 21 & 16 & 22 & 22 & 21 & 10 & 14 & 6 & 4 & 10 & 14 & 8.4 & High \\
\hline 26 & 18 & 27 & 28 & 22 & 16 & 15 & 14 & 19 & 2 & 7 & 10 & 16 & 2 & 7.6 & very high \\
\hline 27 & 3 & 22 & 22 & 19 & 17 & 23 & 19 & 11 & 8 & 2 & 1 & 17 & 8 & 7.5 & very high \\
\hline 28 & 21 & 26 & 7 & 10 & 18 & 24 & 15 & 13 & 4 & 9 & 13 & 14 & 4 & 8.5 & High \\
\hline 29 & 20 & 24 & 29 & 21 & 23 & 16 & 20 & 20 & 6 & 4 & 2 & 9 & 6 & 7.7 & High \\
\hline
\end{tabular}

(Fig. 8h). Sub-watersheds 1, 8, 17, 19, 20, and 22 have low $G r$ values. The $G r$ values are high in sub-watersheds 16,18 , 27 , and 29 denoting that runoff potential is high (Table 7).

\section{Hypsometric integral (HI)}

It is used to depict the percentage of an area of the surface at various altitudes above and below.

(Chai, 2014). It is an indicator to determine the health or condition of the watershed. The HI of the watershed was observed to be 0.22 , which is low, and it indicates an old (monadnock) stage largely influenced by erosion. Across the 29 sub-watersheds, HI ranges from 0.10 to 0.40 (Fig. 9a and Table 8). Of the 29 sub-watersheds, five are in the mature stage and susceptible to erosion. Sub-watershed 21 is the most susceptible to erosion and high in accumulation of sediments because the main outlet of the entire watershed is in this sub-watershed. Twenty-four sub-watersheds are in the old stage. Figure $9 \mathrm{~b}$ shows that the hypsometric curve of the watershed is concave which connotes that the watershed is old with low relief (Sangma and Balamurugan, 2017).

\section{Sub-watershed prioritization}

The sub-watershed has been categorized into 5 classes as shown in Table 9 and Fig. 10. The values of the compound factors vary from 5.7 (highest) to 11.6 (lowest). Out of 29 sub-watersheds, sub-watersheds 12, 16, 18, 24, 26, and 27 are classified as a very high priority. Sub-watersheds 7, 9, $14,25,28$, and 29 are classified as a high priority while sub-watersheds 2, 3, 6, 11, and 23 are a moderate priority. Sub-watersheds 1, 4, 5, 10, 21, and 22 are classified, as a low priority and sub-watersheds $8,13,17,19$, and 20 are very low priority. Sub-watershed with very low priority indicates 
Fig. 10 Prioritized upper Benue River sub-watershed

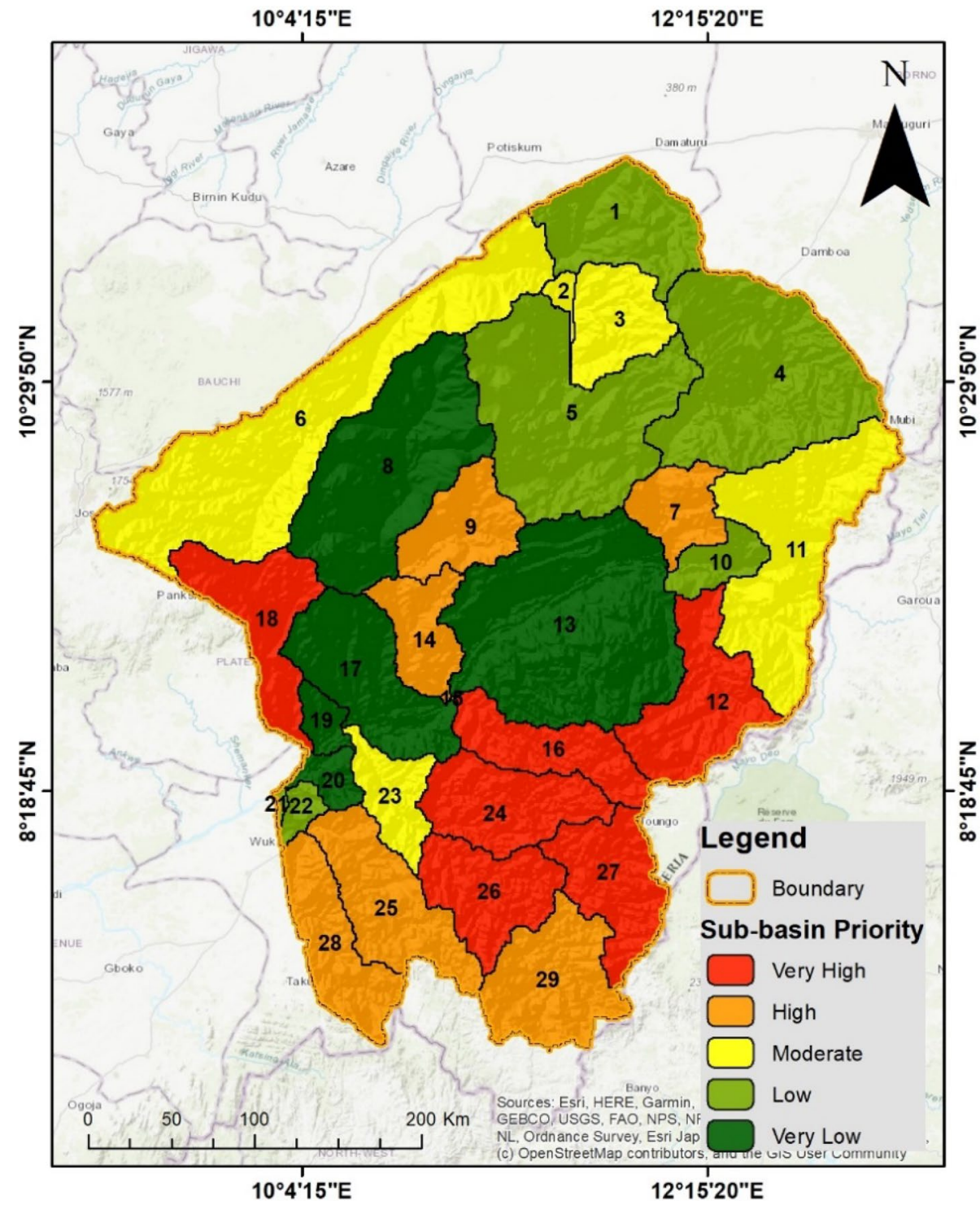

low vulnerability. The very high priority signifies the vulnerability of the sub-watersheds to erosion and flood; hence, Soil and water conservation intervention could be suggested in sub-watersheds with very high and high priorities (Chandniha and Kansal 2017).

\section{Topographic wetness index (TWI)}

The TWI was used to classify areas within the watershed that is likely to be wetter and drier due to runoff (Hojati and Mokarram 2016). TWI of the watershed ranges -15.5 to 12.9 as shown in Fig. 11a. The TWI value is high majorly in lowland areas and along the mainstream channel which indicates a high accumulation of water resulting in high soil moisture and this makes a great potential for water harvesting site. High TWI values can be used as a proxy for identifying floodplain, wetlands, and diversity of species of flora and fauna because a high accumulation of water is essential for their survival. Low TWI value is attributed to steep slopes where water flows rapidly usually in the hilly landscape of the watershed (Besnard et al. 2013).

\section{Asymmetrical factor (AF)}

The AF measures the degree of tilting in a watershed (Nag 1998). Stream network can become asymmetrical due to tilting with more area on one side of the watershed than the other. For this study, the AF was calculated to be $38.1 \%$ which means that the watershed has tilted towards the downstream right side. The mainstream and other larger streams are on the left side of the watershed (Vandana 2013). It, therefore, means $61.9 \%$ of the watershed is tilted towards the downstream left side (Fig. 11b). 

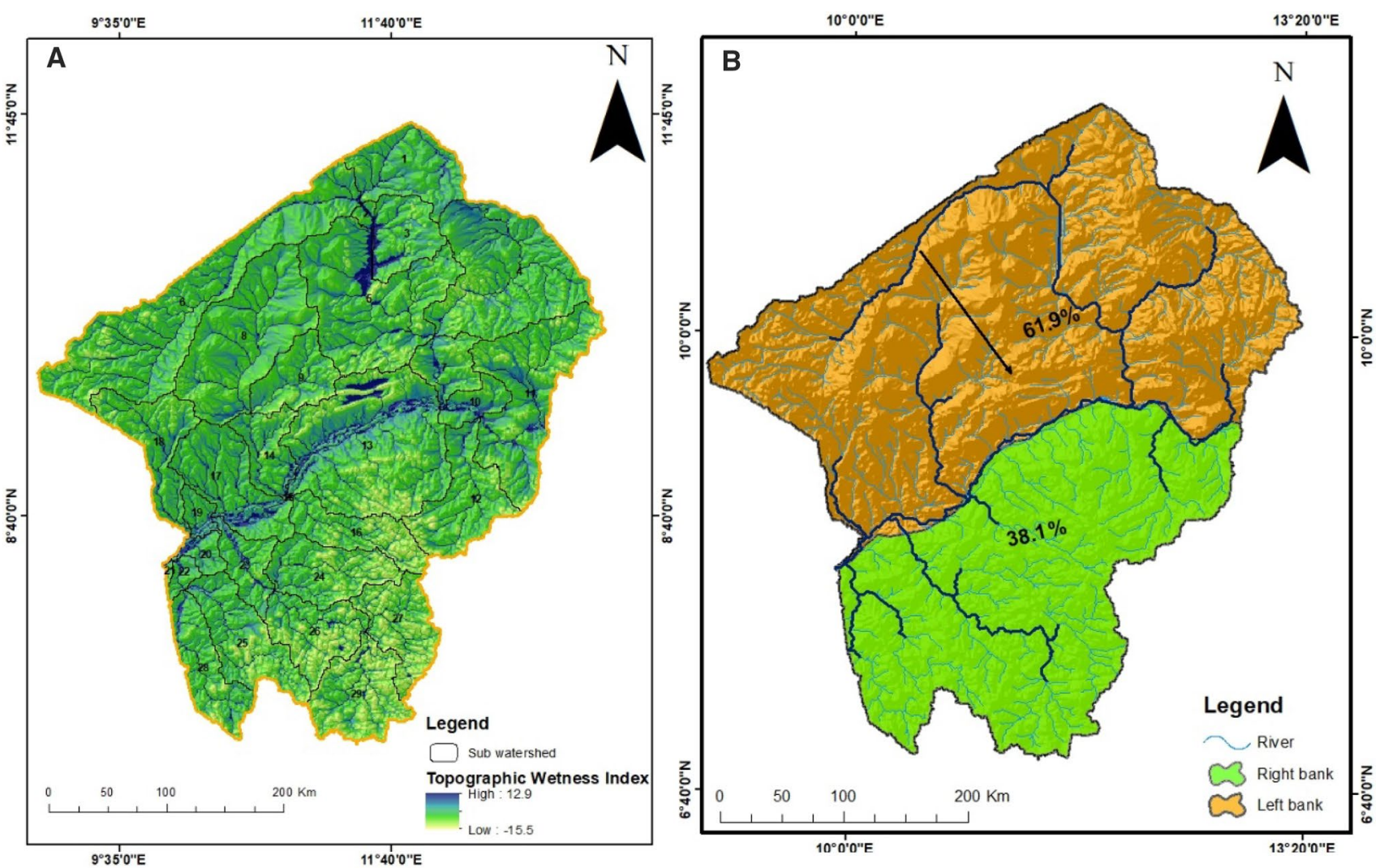

Fig. 11 a Topographic Wetness Index, b Asymmetrical factor

\section{Conclusion}

Topographic data and SRTM DEM integrated with GISenabled quantitative and qualitative morphometric assessment of each of the 28 parameters in 29 sub-watersheds. The upper Benue River watershed is drained by 7 stream orders dominated by the $1^{\text {st }}$ and $2^{\text {nd }}$ order streams both of which account $84.76 \%$ of stream order. The finding of this study showed that the potential for surface runoff, flood and erosion varied across the sub-watersheds as shown from its stream frequency, infiltration number, drainage density, drainage texture and relief ratio analysis. The low elongation ratio and form factor values indicate that the watershed is elongated. Finding from the study also revealed that the hypsometric integral of the watershed is low indicating that it is in the old stage. Out of the 29 sub-watershed, sub-watersheds 12, 16, 18, 24, 26, and 27 are classified as a very high priority hence, susceptible to erosion, and flood. The very high priority areas were suggested for watershed management measures to mitigate the risk of flood and erosion. The upper Benue River watershed holds many potentials especially in agriculture, electricity generation, water resources management, and flood mitigation. Parts of the watershed with 4th, 5th, 6th, and 7 th order streams are suitable for dam construction

for irrigation farming, power generation, and supply of water for domestic use. A water harvesting structure may be required in areas with 1 st and 2 nd stream order to check the speed of surface runoff. The drainage density varies across the watershed; however, sub-watershed with high drainage density should be considered for all year agriculture and power generation. Areas with high drainage density are vulnerable to flood hence drainage infrastructure would be required to channel runoff to stream. The significance of the morphometric and prioritization of the upper Benue River watershed is that it will help in the watershed and natural resources management.

Acknowledgements We are grateful to the department of Strategic Space Application, National Space Research and Development Agency, Abuja, Nigeria for supporting this study. We also appreciate the Office of the Surveyor-General of the Federation (OSGOF) and the Federal Ministry of Water Resources for providing some of the data for this study.

Funding This study was not funded by any organization or institution.

\section{Compliance with ethical standards}

Conflict of Interest The authors declare that there is no conflict of interest. 
Open Access This article is licensed under a Creative Commons Attribution 4.0 International License, which permits use, sharing, adaptation, distribution and reproduction in any medium or format, as long as you give appropriate credit to the original author(s) and the source, provide a link to the Creative Commons licence, and indicate if changes were made. The images or other third party material in this article are included in the article's Creative Commons licence, unless indicated otherwise in a credit line to the material. If material is not included in the article's Creative Commons licence and your intended use is not permitted by statutory regulation or exceeds the permitted use, you will need to obtain permission directly from the copyright holder. To view a copy of this licence, visit http://creativecommons.org/licenses/by/4.0/.

\section{References}

Ajibade LT, *Ifabiyi IP, *Iroye, KA, *Ogunteru S (2010) Morphometric Analysis of Ogunpa and Ogbere Drainage Basins, Ibadan, Nigeria. *Ajibade, L.T., *Ifabiyi, I.P., *Iroye, K.A. and *Ogunteru, S. J Eth Stud Environ Vol Manag, 3(1).

Altaf F, Meraj G, Romshoo SA (2013) Morphometric analysis to infer hydrological behaviour of lidder watershed. Geogr J, Western Himalaya, India. https://doi.org/10.1155/2013/178021

Arabameri A, Tiefenbacher JP, Blaschke T, Pradhan B, Bui DT (2020) Morphometric analysis for soil erosion susceptibility mapping using novel gis-based ensemble model. Remote Sens. https://doi.org/10.3390/rs12050874

Asfaw D, Workineh G (2019) Quantitative analysis of morphometry on Ribb and Gumara watersheds: Implications for soil and water conservation. Int Soil Water Conserv Res 7(2):150-157. https ://doi.org/10.1016/j.iswcr.2019.02.003

Besnard AG, La Jeunesse I, Pays O, Secondi J (2013) Topographic wetness index predicts the occurrence of bird species in floodplains. Divers Distrib 19(8):955-963. https://doi.org/10.1111/ ddi. 12047

Beven KJ, Kirkby MJ (1979) A physically based, variable contributing area model of basin hydrology. HydrolSci Bull 24(1):43-69. https://doi.org/10.1080/02626667909491834

Biswas A, Das Majumdar D, Banerjee S (2014) Morphometry governs the dynamics of a drainage basin: analysis and implications. Geogr J 2014:1-14. https://doi.org/10.1155/2014/927176

Bunmi MR, Yusuf OM, Oladapo AI (2017) Morphometric aAnalysis of Asa and Oyun River Basins, North Central Nigeria Using Geographical Information System. 5(6), 379-393. https://doi. org/https://doi.org/10.11648/j.ajce.20170506.20

Carlston CW (1963) Drainage density and streamflow. U.S. Geol. Surv. Prof. Pap. No. 42, 2-C, 8pp.

Chai R (2014) Morphometric analysis of Digaru river basin, Lohit District, Arunachal Pradesh. IOSR J Environ SciToxicol Food Technol 8(10):30-49

Chandniha SK, Kansal ML (2017) Prioritization of sub-watersheds based on morphometric analysis using the geospatial technique in Piperiya watershed. India Appl Water Science 7(1):329-338. https://doi.org/10.1007/s13201-014-0248-9

Chang K (2014) Introduction to geographic information systems. McGraw-Hill, Cambridge

Chorley RJ, Malm DEG, Pogorzelski HA (1957) A new standard for estimating drainage basin shape. Am J Sci 255(2):138-141

Chow, V. Te. (1964). Handbook of applied hydrology.

Clarke, J. I. (1966). Morphometry from maps. Essays Geomorph, 235-274.

Das S, Pardeshi SD (2018) Morphometric analysis of Vaitarna and Ulhas river basins, Maharashtra, India: using geospatial techniques. Applied Water Science 8(6):1-11. https://doi. org/10.1007/s13201-018-0801-z

Dubey SK, Sharma D, Mundetia N (2015) Morphometric analysis of the banas river basin using the geographical information system Rajasthan India. Hydrology 3(5):47. https://doi.org/10.11648 /j.hyd.20150305.11

Ezeh CU, Mozie AT (2019) Correction to: Morphometric analysis of the Idemili Basin using geospatial techniques. Arab J Geosci 12(9):298. https://doi.org/10.1007/s12517-019-4469-y

Faniran A (1968) The index of drainage intensity - a provisional new drainage factor. Aust J Sci 31:328-330

Fenta AA, Yasuda H, Shimizu K, Haregeweyn N, Woldearegay K (2017) Quantitative analysis and implications of drainage morphometry of the Agula watershed in the semi-arid northern Ethiopia. Appl Water Sci 7(7):3825-3840. https://doi.org/10.1007/s1320 1-017-0534-4

Forest Management Bureau (2011) Watershed characterization and vulnerability assessment using geographic information system and remote sensing. https://doi.org/https://doi.org/10.1109/isqed .2008 .4479675

Gardner TW, Back W, Bullard TF, Hare PW, Kesel RH, Lowe DR, Menges CM, Mora SC, Pazzaglia FJ, Sasowsky ID (1987) Central America and the Caribbean. GeomorSyst North Am Bould Color GeolSoc Am Cent Special 2:343-402

Gravelius, H. (1914). Flusskunde (vol. 1). GJ göschen

Hadley RF, Schumm SA (1961) Sediment sources and drainage basin characteristics in upper Cheyenne River basin. US GeolSurv Water Supply Paper 1531:198

Hajam RA, Hamid A, Bhat, and S. (2013) Application of morphometric analysis for geo-hydrological studies using geo-spatial technology-A Case Study of Vishav Drainage Basin. J Waste Water Treat Anal. https://doi.org/10.4172/2157-7587.1000157

Hare PW, Gardner TW (1985) Geomorphic indicators of vertical neotectonism along converging plate margins, Nicoya Peninsula, Costa Rica. Tectonic Geomorphology 4:75-104

Horton RE (1932) Drainage-basin characteristics. Eos, Trans Am Geophys Union 13(1):350-361

Horton RE (1945) Erosional Development of Streams and their Drainage Basins; Hydrophysical Approach to Quantitative Morphology. GSA Bull 56(3):275-370. https://doi.org/10.1130/00167606(1945)56[275:EDOSAT]2.0.CO;2

Ishaku JM, Ankidawa BA, Abbo A (2015) Groundwater quality and hydrogeochemistry of Toungo Area Adamawa State North-Eastern Nigeria. Am J Min Metall 3(3):63-73. https://doi.org/10.12691/ ajmm-3-3-2

Kale VS, Sengupta S, Achyuthan H, Jaiswal MK (2014) Tectonic controls upon Kaveri River drainage, cratonic Peninsular India: Inferences from longitudinal profiles, morphotectonic indices, hanging valleys and fluvial records. Geomorphology 227:153165. https://doi.org/10.1016/j.geomorph.2013.07.027

Kaliraj S, Chandrasekar N, Magesh NS (2015) Morphometric analysis of the River Thamirabarani sub-basin in Kanyakumari District, Southwest coast of Tamil Nadu, India, using remote sensing and GIS. Environ Earth Sci 73(11):7375-7401. https://doi. org/10.1007/s12665-014-3914-1

Keller EA, Pinter N (2002) Active tectonics earthquakes, uplift, and landscape. Prentice-Hall, Cambridge

Langbein; W.B. (1947). Topographic Characteristics of Drainage Basins. US Geological Society Water-Supply Paper 968-C. http://pubs.usgs.gov/wsp/0968c/report.pdf

Luo Y, Su B, Yuan J, Li H, Zhang Q (2011) GIS techniques for watershed delineation of SWAT model in plain polders. Proc Environ Sci 10:2050-2057. https://doi.org/10.1016/j.proen v.2011.09.321

Mahala A (2019) The significance of morphometric analysis to understand the hydrological and morphological characteristics 
in two different morpho-climatic settings. Appl Water Sci 10(1):1-16. https://doi.org/10.1007/s13201-019-1118-2

Majid H, Marzieh M (2016) Determination of a Topographic. Wetness Index Using High. 7(4):41-52

Markose VJ, Jayappa KS (2011) Hypsometric analysis of Kali River Basin, Karnataka, India, using geographic information system. GeocartoInt 26(7):553-568. https://doi.org/10.1080/10106 049.2011.608438

Mayomi I, Yelwa MH, Abdussalam B (2019) Geospatial Analysis of Morphometric Characteristics of River 8(3):1-17. https://doi. org/10.5923/j.re.20180803.03

Melton MA (1957) An analysis of the relations among elements of climate, surface properties, and geomorphology. Columbia Univ, New York

Miller VC (1953) Quantitative geomorphic study of drainage basin characteristics in the Clinch Mountain area, Virginia and Tennessee. Technical Report (Columbia University. Department of Geology); No. 3.

Mustafa AS, Ahmed UI, Naeem NO (2016) Drainage basin morphometric analysis of galagu valley. J ApplIndSci 4(1):6-12

Nag SK (1998) Morphometric analysis using remote sensing techniques in the Chaka sub-basin, Purulia district, West Bengal. J IndSoc Remote Sens 26(1-2):69-76. https://doi.org/10.1007/ BF03007341

Olszevski N, FernandesFilho EI, da Costa LM, Schaefer CEGR, de Souza E, Costa ODV (2011) Morfologia e aspectoshidrológicos da baciahidrográfica do rioPreto, divisa dos estados do Rio de Janeiro e de Minas Gerais. RevistaÁrvore 35(3):485-492

Oruonye E, Ezekiel B, Atiku H, Baba E, Musa N (2016) Drainage Basin Morphometric Parameters of River Lamurde: Implication for Hydrologic and Geomorphic Processes. J AgricEcol Res Int 5(2):1-11. https://doi.org/10.9734/jaeri/2016/22149

Pande CB, Moharir K (2017) GIS-based quantitative morphometric analysis and its consequences: a case study from Shanur River Basin. Maharashtra India Appl Water Sci 7(2):861-871. https:// doi.org/10.1007/s13201-015-0298-7

Pike RJ, Wilson SE (1971) Elevation-relief ratio, hypsometric integral, and geomorphic area-altitude analysis. GeolSoc Am Bull 82(4):1079-1084

Pophare AM, Balpande US (2014) Morphometric analysis of Suketi river basin, Himachal Himalaya. India J Earth SystSci 123(7):1501-1515. https://doi.org/10.1007/s12040-014-0487-z

Prabhakaran A, Jawahar Raj N (2018) Drainage morphometric analysis for assessing form and processes of the watersheds of Pachamalai hills and its adjoining, Central Tamil Nadu. India Appl Water Sci 8(1):1-19. https://doi.org/10.1007/s13201-018-0646-5

Rai PK, Singh P, Mishra VN, Singh A, Sajan B, Shahi AP (2020) Geospatial approach for quantitative drainage morphometric analysis of varuna river basin. India. J Lands Ecol Czech Repub 12(2):1-25. https://doi.org/10.2478/jlecol-2019-0007

ResmiB. C. \& H. A. MR (2019) Quantitative analysis of the drainage and morphometric characteristics of the Palar River basin, Southern Peninsular India; using bAd calculator (bearing azimuth and drainage) and GIS. Geology, Ecology, and Landscapes 3(4):295307. https://doi.org/10.1080/24749508.2018.1563750

Ritter, D. F., Kochel, R. C., \& Miller, J. R. (2002). Process Geomorphology.

Salami AW, Amoo OT, Adeyemo JA, Mohammed AA, Adeogun AG (2017) Morphometrical analysis and peak runoff estimation for the sub-lower niger river basin. Nigeria Slovak J Civil Eng 24(1):6-16. https://doi.org/10.1515/sjce-2016-0002

Samal DR, Gedam SS, Nagarajan R (2015) GIS-based drainage morphometry and its influence on hydrology in parts of Western Ghats region, Maharashtra. India GeocartoInt 30(7):755-778. https:// doi.org/10.1080/10106049.2014.978903
Sangma F, Balamurugan G (2017) Morphometric Analysis of kakoi river watershed for study of neotectonic activity using geospatial technology. Int J Geosci 08(11):1384-1403. https://doi. org/10.4236/ijg.2017.811081

Schumm SA (1956) Evolution of Drainage Systems and Slopes in Badlands at Perth Amboy. New Jersey GSA Bull 67(5):597-646. https ://doi.org/10.1130/0016-7606(1956)67[597:EODSAS]2.0.CO;2

Sharma SK, Rajput GS, Tignath S, Pandey RP (2010) Morphometric analysis and prioritization of a watershed using GIS. J Indian Water ResourcSoc 30(2):33-39

SINGH, O. (2009) Hypsometry and erosion proneness: a case study in the lesser Himalayan Watersheds. J Soil Water Conserv $8(2): 53-59$

Singh S, Singh MC (1997) Morphometric analysis of Kanhar river basin. NatlGeogr J India 43(1):31-43

Smith KG (1958) Erosional processes and landforms in badlands national monument. South Dakota GSA Bull 69(8):975-1008. https ://doi.org/10.1130/0016-7606(1958)69[975:EPALI B]2.0.CO;2

Softa M, Emre T, Sözbilir H, Spencer JQG, Turan M (2018) Geomorphic evidence for active tectonic deformation in the coastal part of Eastern Black Sea, Eastern Pontides. Turkey GeodinamicaActa 30(1):249-264. https://doi.org/10.1080/09853111.2018.1494776

Sreedevi PD, Owais S, Khan HH, Ahmed S (2009) Morphometric analysis of a watershed of South India using SRTM data and GIS. J GeolSoc India 73(4):543-552. https://doi.org/10.1007/ s12594-009-0038-4

SrinivasaVittala S, Govindaiah S, HonneGowda H (2004) Morphometric analysis of sub-watersheds in the pavagada area of Tumkur district, South India using remote sensing and gis techniques. J IndSoc Remote Sens 32(4):351-362. https://doi.org/10.1007/ BF03030860

Strahler AN (1964a) Quantitative geomorphology of basin and channel networks: handbook of applied hydrology. Mcgraw Hill Book Company, New York

Strahler AN (1952) Hypsometric (area-altitude) analysis of erosional topography. Bull GeolSoc Am. https://doi.org/10.1130/00167606(1952)63[1117:HAAOET]2.0.CO;2

Strahler AN (1957) Quantitative analysis of watershed geomorphology. Eos Trans Am Geophys Union. https://doi.org/10.1029/TR038 i006p00913

Strahler AN (1964b) Part II. Quantitative geomorphology of drainage basins and channel networks. Handbook of applied hydrology. McGraw-Hill, New York, pp 4-39

Sukristiyanti S, Maria R, Lestiana H (2018) Watershed-based morphometric analysis: a review. IOP Conf Ser Earth Environ Sci. https ://doi.org/10.1088/1755-1315/118/1/012028

Taofik OK, Innocent B, Christopher N, Jidauna GG, James AS (2017). A comparative analysis of drainage morphometry on hydrologic characteristics of kereke and ukoghor basins on flood vulnerability in makurdi town, Nigeria. Hydrology, 5(3): 32 https://doi. org/https://doi.org/10.11648/j.hyd.20170503.11

Tarboton DG (1997) A new method for the determination of flow directions and upslope areas in grid digital elevation models. Water Resour Res 33(2):309-319. https://doi.org/10.1029/96WR03137

Thomas J, Joseph S, Thrivikramaji KP (2010) Morphometric aspects of a small tropical mountain river system, the southern Western Ghats. India Int J Digital Earth 3(2):135-156

Tucker GE, Bras RL (1998) Hillslope processes, drainage density, and landscape morphology. Water Resour 34(10):2751-2764

Umrikar BN (2017) Morphometric analysis of Andhale watershed, TalukaMulshi, District Pune. India Appl Water Sci 7(5):22312243. https://doi.org/10.1007/s13201-016-0390-7

Vandana M (2013) Morphometric analysis and watershed prioritisation: a case study of Kabani river basin, Wayanad District, Kerala. India Ind J Mar Sci 42(2):211-222

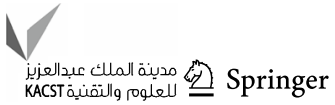


Venkatesh M, Anshumali. (2019) A GIS-based assessment of recent changes in drainage and morphometry of Betwa River basin and sub-basins. Central India Appl Water Sci 9(7):1-12. https://doi. org/10.1007/s13201-019-1033-6

Waiyasusri K, Chotpantarat S (2020) Watershed Prioritization of KaengLawa Sub- Watershed. A Case Study of Heavy Flooding Caused by Tropical Storm Podul, KhonKaen Province Using the Morphometric and Land-Use Analysis. https://doi.org/10.3390/ w12061570
Wilson J, Gallant J (2000) Digital terrain analysis. Terrain Anal Princip Appl 479:1-27

Withanage NS, Dayawansa NDK, De Silva RP (2015) Morphometric analysis of the $\mathrm{Gal}$ Oya river basin using spatial data derived from GIS. Trop Agric Res 26(1):175. https://doi.org/10.4038/tar.v26i1 .8082

Publisher's Note Springer Nature remains neutral with regard to jurisdictional claims in published maps and institutional affiliations. 